\title{
Evaluation of impacts of future climate change and water use scenarios on regional hydrology
}

\author{
Seungwoo Chang ${ }^{1}$, Wendy Graham ${ }^{1,2}$, Jeffrey Geurink ${ }^{3}$, Nisai Wanakule ${ }^{3}$, and Tirusew Asefa ${ }^{3}$ \\ ${ }^{1}$ Water Institute, University of Florida, 570 Weil Hall, P.O. Box 116601, Gainesville, FL 32611, USA \\ ${ }^{2}$ Department of Agricultural and Biological Engineering, University of Florida, 570 Weil Hall, P.O. Box 116601, \\ Gainesville, FL 32611, USA \\ ${ }^{3}$ Tampa Bay Water, 2575 Enterprise Rd, Clearwater, FL 33763-1102, USA
}

Correspondence: Seungwoo Chang (swjason@ufl.edu)

Received: 23 February 2018 - Discussion started: 26 March 2018

Revised: 31 July 2018 - Accepted: 10 August 2018 - Published: 17 September 2018

\begin{abstract}
General circulation models (GCMs) have been widely used to simulate current and future climate at the global scale. However, the development of frameworks to apply GCMs to assess potential climate change impacts on regional hydrologic systems, ability to meet future water demand, and compliance with water resource regulations is more recent. In this study eight GCMs were bias-corrected and downscaled using the bias correction and stochastic ana$\log$ (BCSA) downscaling method and then used, together with three $\mathrm{ET}_{0}$ methods and eight different water use scenarios, to drive an integrated hydrologic model previously developed for the Tampa Bay region in western central Florida. Variance-based sensitivity analysis showed that changes in projected streamflow were very sensitive to GCM selection, but relatively insensitive to $\mathrm{ET}_{0}$ method or water use scenario. Changes in projections of groundwater level were sensitive to both GCM and water use scenario, but relatively insensitive to $\mathrm{ET}_{0}$ method. Five of eight GCMs projected a decrease in streamflow and groundwater availability in the future regardless of water use scenario or ET method. For the business as usual water use scenario all eight GCMs indicated that, even with active water conservation programs, increases in public water demand projected for 2045 could not be met from ground and surface water supplies while achieving current groundwater level and surface water flow regulations. With adoption of $40 \%$ wastewater reuse for public supply and active conservation four of the eight GCMs indicate that 2045 public water demand could be met while achieving current environmental regulations; however, drier climates would require a switch from groundwater to surface water
\end{abstract}

use. These results indicate a high probability of a reduction in future freshwater supply in the Tampa Bay region if environmental regulations intended to protect current aquatic ecosystems do not adapt to the changing climate. Broad interpretation of the results of this study may be limited by the fact that all future water use scenarios assumed that increases in water demand would be the result of intensification of water use on existing agricultural, industrial, and urban lands. Future work should evaluate the impacts of a range of potential land use change scenarios, with associated water use change projections, over a larger number of GCMs.

\section{Introduction}

The Intergovernmental Panel on Climate Change (IPCC) along with many other studies have indicated that climate change is likely to alter both the global hydrologic cycle and regional hydrologic cycles (Aalst et al., 2014; Déry et al., 2009; Georgakakos et al., 2014; Hawkins et al., 2014; Milliman et al., 2008). These studies have indicated that climate change is likely to increase the frequency of droughts, as well as the magnitude of floods in many regions (Diffenbaugh and Field, 2013; Georgakakos et al., 2014; Walsh et al., 2014). It is necessary to investigate future climate change and its potential impacts on the natural environment in order to reduce risks and increase resilience for future water resource planning and management (Vano and Lettenmaier, 2013). 
General circulation models (GCMs) and hydrologic models have been widely used to evaluate future climate change and its impact on regional hydrologic cycles (Boé et al., 2007; Maurer and Hidalgo, 2008). However, there are a variety of barriers to direct use of GCMs to drive regional hydrologic models. For example, the current generation of GCMs contains biases that prevent accurate reproduction of historic hydrological conditions when used to drive hydrologic models (Giorgi and Mearns, 2002; Wood et al., 2002). In addition, the coarse resolution of GCMs prevents direct use of their results with regional hydrologic models that require higher-resolution climate variables (Solomon et al., 2007). Many bias-correction methods and downscaling methods have been developed and evaluated to overcome these limitations (Chen et al., 2013; Ghosh and Mujumdar, 2008; Hwang and Graham, 2013; Langousis et al., 2016; Muerth et al., 2013; Quintana Seguí et al., 2010; Stoll et al., 2011; Zhang and Georgakakos, 2012). Although these bias-correction and downscaling methods do not correct problems with large-scale synoptic forcing, and are not particularly good at reproducing extreme floods or droughts in the retrospective period, previous research has shown that they are able to simulate broad features of the climate system and are useful for characterizing plausible projections of possible futures (Kundzewicz et al., 2008, 2009). Furthermore, previous work in the study region has shown that hydrologic models driven by bias-corrected downscaled retrospective GCM output adequately reproduce retrospective high stream flows (e.g., 7Q2 and 7Q10), as well as the longterm mean and standard deviation of monthly flows (Hwang and Graham, 2014).

In addition to studies that focus on climate impacts on the hydrological cycle, it is also necessary to evaluate the effects of direct human behavior (Haddeland et al., 2014; Wang and Hejazi, 2011). Human activities such as agricultural production, irrigation (Gupta et al., 2015), municipal pumping (Patterson et al., 2013), deforestation, and urban development alter regional hydrologic behavior (Siriwardena et al., 2006). For robust water resource management and planning better understanding of the influence and relative importance of climate change and human-induced change on hydrology and water resources is essential (J. Chang et al., 2016; Ma et al., 2008; Tan and Gan, 2015; Ye et al., 2013; Zheng et al., 2009).

The relative contributions of climate change and human activities to hydrologic responses have been evaluated using GCM data to drive hydrologic models with plausible future anthropogenic scenarios (Liu et al., 2013; Maurer et al., 2010; Wood et al., 2002). Murray et al. (2012) used the Land-surface Processes and eXchanges (LPX) dynamic global vegetation model and the WaterGAP hydrological model to evaluate the impacts of climate change and socio-economic change on global hydrologic response for the 2070-2099 time period. They found that climate change and population growth increased water stress in many re- gions, and change in runoff was most highly correlated with precipitation change in large global catchments. Harding et al. (2012) applied downscaled outputs of 16 GCMs with the VIC model to investigate the future change in streamflow for the Colorado River basin. They suggested that impact analyses relying on only a few scenarios were unacceptably influenced by the choice of GCM projections.

For studies using GCMs to project future hydrologic responses, uncertainties resulting from the choice of GCM, RCP (representative concentration pathway) trajectory, and reference evapotranspiration $\left(\mathrm{ET}_{0}\right)$ estimation methods are all significant, and it is important to quantify the relative uncertainties of these factors (S. Chang et al., 2016; Hawkins and Sutton, 2009, 2010; Kingston et al., 2009; Koedyk and Kingston, 2016; McAfee, 2013; Thompson et al., 2014; Wang et al., 2015). Furthermore, the effects of climate change on groundwater levels have not been explored as extensively as the effects of climate change on surface water flows (Green et al., 2011; Kløve et al., 2014). Kløve et al. (2014) suggested that the uncertainties of groundwater projections attributed to climate models, downscaling techniques, emission scenarios, land use changes, and social economic development should be evaluated.

This study evaluated the future projections of regional hydrologic response using eight GCMs, three $\mathrm{ET}_{0}$ estimation methods, and eight human water use scenarios to drive a calibrated regional hydrologic model developed for the Tampa Bay region. A comprehensive evaluation of the relative sensitivity of projections of regional hydrologic response to the choice of GCM, $\mathrm{ET}_{0}$ estimation method, and human water use scenario was conducted. Statistical analyses were performed to determine whether differences in streamflow and groundwater level between retrospective hydrologic and projected future climate were statistically significant given these underlying prediction uncertainties. The ability to satisfy projected increases in future water demand while meeting current groundwater level and surface water flow regulations was evaluated over the suite of GCM and water management scenarios.

\section{Materials and methods}

\subsection{Study region}

Tampa Bay Water operates a diverse regional water supply system comprised of a desalination plant, well fields that extract water from the Floridan aquifer, and surface water that is extracted from the Hillsborough and Alafia rivers (https://tampabaywater.org/ water-supply-sources-tampa-bay-region, last access: 1 September 2018). The fresh groundwater system in the region is composed of two aquifer systems, a thin surficial aquifer and the thick and highly productive carbonate rocks of the Floridan aquifer system (Tihansky and Knochenmus, 


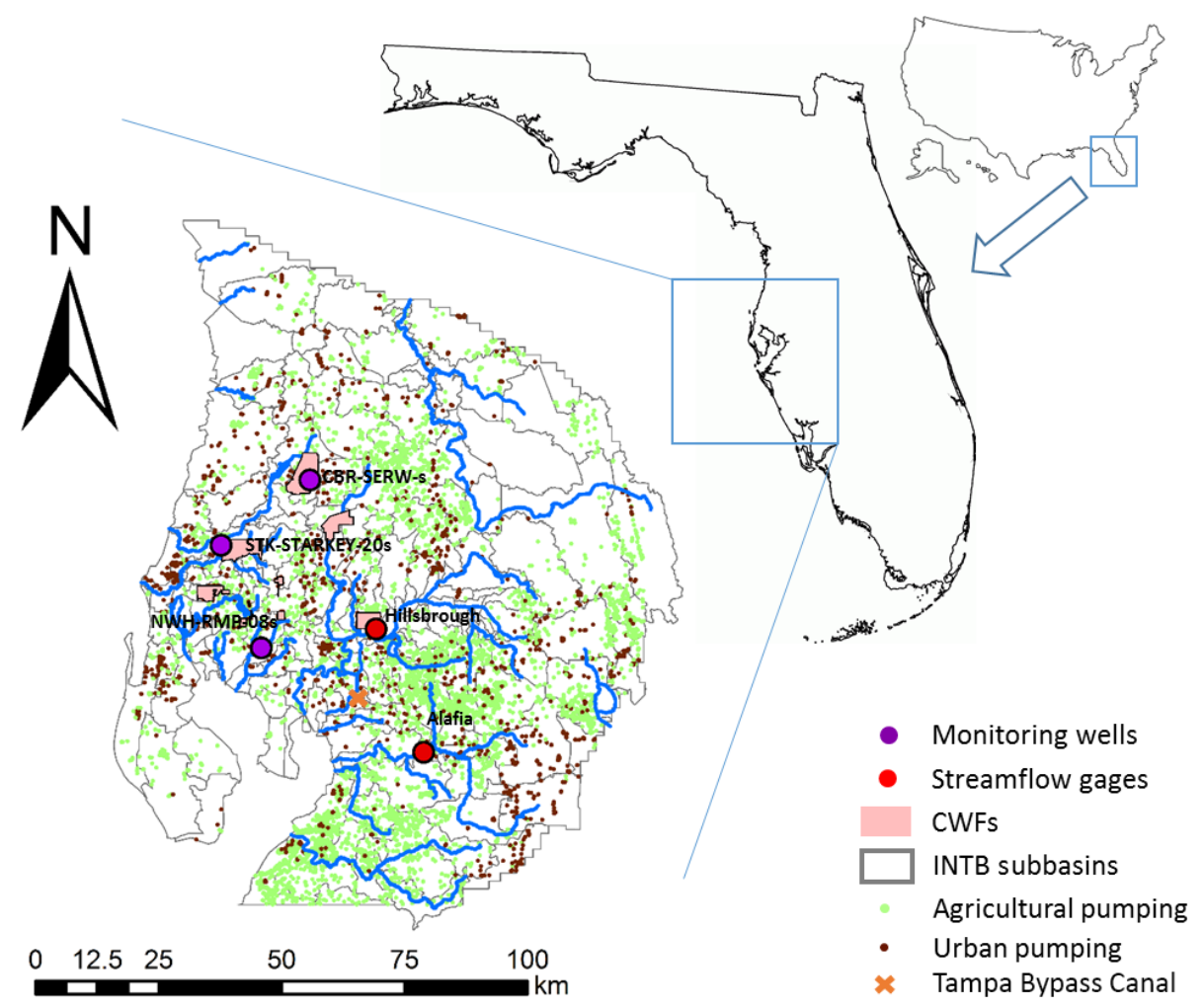

Figure 1. Study region showing the INTB model domain and locations of agricultural, industrial, and public water supply wells, the Tampa Bay Water Consolidated Wellfields (CWFs), two streamflow locations where water is withdrawn for public supply, the Tampa Bay Bypass Canal, and three monitoring wells near Tampa Bay Water's CWFs that are used to evaluate compliance with groundwater level regulations.

2001). Dynamic interacting surface-water and groundwater systems (in which groundwater from the aquifer used for agricultural irrigation and public water supply also feed the surface springs and rivers) characterize the region and must be considered in the management of water resources (Tihansky, 1999). For example, the SWFWMD regulates groundwater pumping for water supply to maintain groundwater levels that promote environmental protection of lakes and wetlands near well fields. Similarly they regulate the daily volume of flow permitted for extraction from rivers based on maintaining sufficient in-stream flows and spring flows to protect aquatic ecosystems.

This study focused on the Integrated Northern Tampa Bay (INTB) model domain (Geurink and Basso, 2013; Hwang and Graham, 2014). Figure 1 shows the INTB model domain, model sub-basins, locations of agricultural, industrial, and public water supply wells, two streamflow locations where water is withdrawn for public supply, and three monitoring wells near Tampa Bay Water's consolidated well fields that are used to evaluate compliance with groundwater level regulations. The INTB region land use currently consists of grass/pasture $(25 \%)$, urban $(22 \%)$, forested $(15 \%)$, mining/other (7\%), agriculture/irrigated land $(6 \%)$, open water $(4 \%)$, and wetlands $(21 \%)$.

\subsection{The Integrated Northern Tampa Bay model}

Tampa Bay Water and the Southwest Florida Water Management District (SWFWMD) developed the Integrated Hydrologic Model (IHM) simulation engine which integrates the EPA Hydrologic Simulation Program-Fortran (Bicknell et al., 2005) for surface water modeling with the U.S. Geological Survey (USGS) MODFLOW96 (Harbaugh and McDonald, 1996) for groundwater modeling. The IHM simulates the dynamic interaction of surface water and groundwater systems within the INTB region, including all processes which affect flow and water levels in uplands, within the unsaturated soil, and within wetlands, rivers, and aquifers. In addition, the INTB model can account for variability in climate and anthropogenic stresses such as land use change, groundwater pumping, and diversions to/from rivers, lakes, and wetlands.

Tampa Bay Water and the SWFWMD calibrated model parameters to simulate streamflows, groundwater levels, and wetland hydroperiods in the INTB model region. The INTB model was calibrated from 1989 to 1998 and verified from 1999 to 2006 (Geurink and Basso, 2013). Precipitation data for calibrating and validating the model were obtained from 302 point gages maintained by the National Oceanic and Atmospheric Administration (NOAA), the SWFWMD, and 
Tampa Bay Water in the model region. Maximum and minimum daily temperatures were obtained from six NOAA stations within the INTB region and used to estimate $\mathrm{ET}_{0}$ using the Hargreaves method. Over the calibration and validation period (1989 to 2006) average annual precipitation input to the model was $1308 \mathrm{~mm} \mathrm{yr}^{-1}$ and average annual actual evapotranspiration estimated by the model was $940 \mathrm{~mm} \mathrm{yr}^{-1}$, resulting in net available water (precipitationactual evapotranspiration) of $368 \mathrm{~mm} \mathrm{yr}^{-1}$. During this period surface discharge from the domain was $272 \mathrm{~mm} \mathrm{yr}^{-1}$ (74\% of net available water), groundwater pumping was $69 \mathrm{~mm} \mathrm{yr}^{-1}(19 \%)$, surface water diversions for water supply were $10 \mathrm{~mm} \mathrm{yr}^{-1}(3 \%)$, and irrigation applied within the domain was $18 \mathrm{~mm} \mathrm{yr}^{-1}(5 \%)$. More details about the processes and results of model calibration and validation are described in Geurink and Basso (2013).

Streamflow predictions at two United States Geological Survey (USGS) gaging stations, the Hillsborough River (USGS ID: 02303330) and Alafia River (USGS ID: 02301500), were used in this study to evaluate retrospective and future IHM streamflow predictions and quantities of surface water available for public supply. Three Tampa Bay Water monitoring wells (NWH-RMP-08s, CBR-SERW$\mathrm{s}$, and STK-STARKEY-20s) were used to evaluate retrospective and future groundwater level predictions and compliance with environmental regulations intended to protect nearby wetlands from dewatering as a result of consolidated well field pumping.

\subsection{Climate data}

Forcing data from Phase 2 of the North American Land Data Assimilation System (NLDAS-2) from 1982 to 2005 were used as historical reference climate data for bias correction. Hourly precipitation, air temperature, solar radiation (surface downward longwave radiation and surface downward shortwave radiation), surface pressure, and average wind speed were obtained from the NLDAS- 2 archive and aggregated to the daily scale at a $1 / 8$ th-degree grid spacing over the Tampa Bay region.

For retrospective and future climate data, the Coupled Model Intercomparison Project 5 (CMIP5) GCM data set for the 1982-2005 period was used for the retrospective period, and 2030-2060 (future 1) and 2070-2100 (future 2) were used as future periods. Gridded daily precipitation, air temperature, solar radiation, surface pressure, and average wind speed were obtained for eight GCMs listed in Table 1. These GCMs were chosen because they spanned the range of cool to warm bias and wet to dry bias exhibited by 41 CMIP5 GCMs for the southeastern United States (Rupp, 2016), and they had daily values available for all the parameters needed to estimate Penman-Monteith reference evapotranspiration. Mean changes in precipitation projected by these GCMs ranged from -68 to $293 \mathrm{~mm} \mathrm{yr}^{-1}$ over the 2030-2060 period, and from 154 to $400 \mathrm{~mm} \mathrm{yr}^{-1}$ over the $2070-2100$ pe- riod. Mean changes in $\mathrm{ET}_{0}$ ranged from 24 to $137 \mathrm{~mm} \mathrm{yr}^{-1}$ over the 2030-2060 period and from 122 to $351 \mathrm{~mm} \mathrm{yr}^{-1}$ over the 2070-2100 period. Mean changes in $P-\mathrm{ET}_{0}$ ranged from -162 to $220 \mathrm{~mm} \mathrm{yr}^{-1}$ over the 2030-2060 period and from -420 to $159 \mathrm{~mm} \mathrm{yr}^{-1}$ over the 2070-2100 period (Table 1).

S. Chang et al. (2016) evaluated projected changes in $P-$ $\mathrm{ET}_{0}$ over the continental USA using nine GCMs, $10 \mathrm{ET}_{0}$ estimation methods, and three RCP scenarios. They showed that the first-order sensitivities of water deficit projections $\left(P-\mathrm{ET}_{0}\right)$ over the southeastern USA were much higher to choice of GCM and $\mathrm{ET}_{0}$ estimation method than to choice of RCP. First-order sensitivities of water deficit projections to RCP scenarios were negligible $(<0.01)$ for the 2030-2060 time period, and averaged 0.2 for the 2070-2100 time period. Therefore for computational efficiency, and to evaluate the influence of the most extreme carbon dioxide forcing on the hydrologic projections, only the RCP 8.5 scenario data were utilized for the future analyses in this study.

\subsection{BCSA downscaling method}

The BCSA downscaling method, developed by Hwang and Graham (2013), was used in this study. Hwang and Graham (2014) showed that BCSA demonstrated better performance than other statistical downscaling methods (i.e., BCSD, Maurer and Hidalgo, 2008, or SDBC, Abatzoglou and Brown, 2012) in reproducing spatiotemporal statistics of both precipitation and daily streamflow in the Tampa Bay region. In particular, the INTB model, when driven by GCMs downscaled using the BCSA method, accurately reproduced frequencies of extreme high and extreme low retrospective streamflows as well as 7Q2 and 7Q10 retrospective streamflows in the Tampa Bay region.

The BCSA method preserves both the cumulative frequency distribution of observed daily precipitation as well as the spatial autocorrelation structure of observed daily precipitation fields. BCSA downscaling consists of two separate steps for bias correction and stochastic analog spatial downscaling. In the first step, a cumulative distribution function (CDF) mapping approach (Block et al., 2009; Hwang et al., 2013, 2014; Hwang and Graham, 2014; Ines and Hansen, 2006; Teutschbein and Seibert, 2012) is used to reduce the biases in raw GCM output at the GCM scale. In this study, NLDAS-2 $\mathrm{P}$ and $\mathrm{ET}_{0}$ were aggregated up to the GCM scale and $P$ and $\mathrm{ET}_{0}$ from the raw GCMs were bias-corrected at the GCM scale using the sequential univariate CDF mapping method (Chang, 2017). NLDAS-2 was selected for bias correction because it includes all the parameters needed to estimate Penman-Monteith reference evapotranspiration. Comparison of the gridded NLDAS-2 data to the precipitation and temperature observations from the weather stations used to calibrate the INTB model showed that the NLDAS-2 data reproduced observed long-term monthly mean values with biases that ranged from 4 to $12 \mathrm{~mm}$ for daily precipitation and 
Table 1. Description of the CMIP5 models used in this study.

\begin{tabular}{|c|c|c|c|c|c|c|c|c|}
\hline \multirow[t]{3}{*}{ Model } & \multirow[t]{3}{*}{ Institute (country) } & \multirow[t]{3}{*}{ Resolutions } & \multirow[t]{3}{*}{ Calendar } & \multicolumn{2}{|c|}{$\Delta$ Precipitation } & \multicolumn{2}{|c|}{$\Delta \mathrm{ET}_{0}$} & \multirow[t]{3}{*}{ Reference } \\
\hline & & & & \multicolumn{4}{|c|}{$\left(\mathrm{mm} \mathrm{yr}^{-1}\right)^{*}$} & \\
\hline & & & & $\begin{array}{r}2030- \\
2060\end{array}$ & $\begin{array}{r}2070- \\
2100\end{array}$ & $\begin{array}{r}2030- \\
2060\end{array}$ & $\begin{array}{r}2070- \\
2100\end{array}$ & \\
\hline (1) BNU-ESM & $\begin{array}{l}\text { College of Global Change } \\
\text { and Earth System Science, } \\
\text { Beijing Normal University } \\
\text { (China) }\end{array}$ & $\begin{array}{l}2.8^{\circ} \text { lat } \times \\
2.8^{\circ} \text { lon }\end{array}$ & No leap & -68.9 & -57.1 & 93.3 & 273.5 & Ji et al. (2014) \\
\hline (2) GFDL-CM3 & $\begin{array}{l}\text { NOAA/Geophysical } \\
\text { Fluid Dynamics } \\
\text { Laboratory (USA) }\end{array}$ & $\begin{array}{l}2.0^{\circ} \text { lat } \times \\
2.5^{\circ} \text { lon }\end{array}$ & No leap & 293.6 & 400.0 & 133.1 & 351.5 & Guo et al. (2014) \\
\hline (3) GFDL-ESM2G & $\begin{array}{l}\text { NOAA/Geophysical } \\
\text { Fluid Dynamics } \\
\text { Laboratory (USA) }\end{array}$ & $\begin{array}{l}2.0^{\circ} \text { lat } \times \\
2.5^{\circ} \text { lon }\end{array}$ & No leap & -36.8 & -134.6 & 56.2 & 133.5 & $\begin{array}{l}\text { Taylor et } \\
\text { al. (2012) }\end{array}$ \\
\hline (4) MIROC-ESM & $\begin{array}{l}\text { Atmosphere and Ocean } \\
\text { Research Institute, } \\
\text { National Institute for } \\
\text { Environmental Studies, } \\
\text { and Japan Agency for } \\
\text { Marine-Earth Science } \\
\text { and Technology (Japan) }\end{array}$ & $\begin{array}{l}2.8^{\circ} \text { lat } \times \\
2.8^{\circ} \text { lon }\end{array}$ & Leap year & 7.5 & -153.9 & 99.9 & 240.8 & $\begin{array}{l}\text { Watanabe et } \\
\text { al. (2011) }\end{array}$ \\
\hline (5) MPI-ESM-LR & $\begin{array}{l}\text { Max Planck Institute for } \\
\text { Meteorology (Germany) }\end{array}$ & $\begin{array}{l}1.87^{\circ} \text { lat } \times \\
1.87^{\circ} \text { lon }\end{array}$ & Leap year & 105.1 & 77.8 & 81.8 & 230.9 & $\begin{array}{l}\text { Block and } \\
\text { Mauritsen (2013) }\end{array}$ \\
\hline (6) MRI-CGCM3 & $\begin{array}{l}\text { Meteorological Research } \\
\text { Institute (Japan) }\end{array}$ & $\begin{array}{l}1.12^{\circ} \text { lat } \times \\
1.12^{\circ} \text { lon }\end{array}$ & Leap year & 244.2 & 281.2 & 24.4 & 122.1 & $\begin{array}{l}\text { Yukimoto et } \\
\text { al. (2012) }\end{array}$ \\
\hline (7) NorESM1-M & $\begin{array}{l}\text { Norwegian Climate } \\
\text { Centre (Norway) }\end{array}$ & $\begin{array}{l}1.9^{\circ} \text { lat } \times \\
2.5^{\circ} \text { lon }\end{array}$ & No leap & 11.6 & 3.0 & 137.7 & 324.6 & $\begin{array}{l}\text { Bentsen et } \\
\text { al. (2013) }\end{array}$ \\
\hline (8) BCC-CSM1.1 & $\begin{array}{l}\text { Beijing Climate } \\
\text { Center (China) }\end{array}$ & $\begin{array}{l}2.8^{\circ} \text { lat } \times \\
2.8^{\circ} \text { lon }\end{array}$ & No leap & -20.4 & -117.5 & 118.1 & 303.6 & $\begin{array}{l}\text { Xiao-Ge et } \\
\text { al. (2013) }\end{array}$ \\
\hline
\end{tabular}

* Change in precipitation (or $\mathrm{ET}_{0}$ ) is defined as average of future period minus average of retrospective period.

1 to $2{ }^{\circ} \mathrm{C}$ for daily temperature. Correlations among daily values ranged from 0.75 to 0.87 for rainfall and 0.75 to 0.98 for temperature. The second step in the BCSA method is stochastic analog (SA) spatial downscaling (Hwang and Graham, 2013, 2014) for $P$. In this method, a synthetic downscaled precipitation field is produced which preserves the GCM-scale daily precipitation amount and the monthspecific local-scale spatial correlation structure. For more details on the BCSA method, see Hwang and Graham (2013, 2014). $\mathrm{ET}_{0}$ was not downscaled in this study because observed spatial variability of $\mathrm{ET}_{0}$ over the INTB region is very small, and the spatial correlation is large compared to $P$ (Chang, 2017).

\subsection{Reference evapotranspiration estimation methods}

The S. Chang et al. (2016) study referenced above found that the projected changes in $P-\mathrm{ET}_{0}$ were sensitive to both the choice of GCM and the choice of $\mathrm{ET}_{0}$ method, and that for the southeastern USA the choice of GCM and $\mathrm{ET}_{0}$ method had approximately equal influence on changes in future $P$ $\mathrm{ET}_{0}$ throughout most of the year. However, they noted that not all $10 \mathrm{ET}_{0}$ methods were equally appropriate for use in all US regions, and that regional studies should use methods for which retrospective predictions of $\mathrm{ET}_{0}$ are generally consistent with historic observations. Several of the $\mathrm{ET}_{0}$ methods used by S. Chang et al. (2016) were found to produce unreasonably high or low historic $\mathrm{ET}_{0}$ estimates for the study region using retrospective and observation data. Therefore in this study three $\mathrm{ET}_{0}$ estimation methods that are widely used in the southeastern USA produced retrospective predictions that were consistent with observations, and showed that a range of wet to fairly dry projections of future $P-\mathrm{ET}_{0}$ (S. Chang et al., 2016) were included in the analysis. These methods include a temperature-based method (Hargreaves; Hargreaves and Allen, 2003), a radiation-based method (Priestley-Taylor; Allen et al., 1998), and a combination method (Penman-Monteith; Allen et al., 1998). All hourly climate variables described above were aggregated to 
the daily scale and used to calculate daily $\mathrm{ET}_{0}$ using these three methods.

\subsection{Retrospective simulations}

Water use in the study region is comprised of five categories: (1) public supply, (2) agricultural, (3) industrial/commercial, (4) mining, and (5) recreational (e.g., golf course irrigation) (Geurink and Basso, 2013). Groundwater sources are used for agricultural, industrial/commercial, mining, and recreational water supplies. Public water supply is provided by a combination of groundwater, surface water (Hillsborough and Alafia rivers), and a 25 MGD desalinization plant operated by Tampa Bay Water. The SWFWMD regulates all groundwater pumping and surface water extraction in the study region to protect natural aquatic ecosystems and prevent saltwater intrusion. Over the 1989-2006 calibrationverification period groundwater extractions from the INTB model domain averaged $36 \mathrm{~mm} \mathrm{yr}^{-1}$ for public water supply, $18 \mathrm{~mm} \mathrm{yr}^{-1}$ for agricultural irrigation, $9 \mathrm{~mm} \mathrm{yr}^{-1}$ for industrial/commercial uses, $6 \mathrm{~mm} \mathrm{yr}^{-1}$ for mining, and $3 \mathrm{~mm} \mathrm{yr}^{-1}$ for recreational uses (Geurink and Basso, 2013).

Public water supply. Tampa Bay Water has a consolidated permit for its 11 well fields (the Consolidated Wellfields, hereafter referred to as the CWFs). The CWFs are operated as an interconnected system with a combined maximum permitted pumping rate of 90 MGD $\left(13 \mathrm{~mm} \mathrm{yr}^{-1}\right.$ over the INTB region). Individual well pumping rates are optimized to maintain minimum groundwater levels near sensitive wetlands to meet regulatory requirements intended to prevent ecological harm. The three monitoring wells evaluated in this study are located near wetlands adjacent to the CWFs (Fig. 1). From 1992 to 2008 Tampa Bay Water's total water demand average ranged from 150 to 200 MGD. Groundwater is Tampa Bay Water's most inexpensive source of public water supply; therefore, for the retrospective simulations the CWFs were assumed to withdraw groundwater continuously at the 90 MGD maximum permitted rate. For the retrospective simulations groundwater extraction for other public water supply (outside of Tampa Bay Water's CWF), and industrial/commercial and mining uses, were assumed occur continuously at the average pumping rates between years 1989 and 2006 cited above.

Maximum surface water available to Tampa Bay Water for public supply was calculated on a daily basis from retrospective streamflow predictions for both the Hillsborough River and the Alafia River according to site-specific regulations set to maintain sufficient in-stream flows and spring flows to protect aquatic ecosystems. Diversion rates for pumping from the Hillsborough River reservoir by the City of Tampa and from the Tampa Bypass Canal by SWFWMD were set at the historical average daily rate spanning 2003 to 2009 for all retrospective simulations. All other diversion rates were set to zero, including the Withlacoochee-Hillsborough overflow. These diversion locations are located either downstream or outside of the watersheds contributing to the surface water gages, and outside the zone of influence of the monitoring wells evaluated in this study, so these assumptions do not impact on the results (Fig. 1).

Agricultural irrigation demand. The AFSIRS (Agricultural Field-Scale Irrigation Requirements Simulation) model (Jacobs and Dukes, 2007; Smajstrla, 1990) was used to estimate climate-driven irrigation demand for the retrospective period. The AFSIRS model tracks the water budget in the crop root zone including inputs from rain and irrigation, and outputs from the root zone by drainage and evapotranspiration. The AFSIRS model defines the water storage capacity in the crop root zone as the product of the water-holding capacity of the soil (estimated by the difference between field capacity and wilting point) and the depth of the effective root zone for the crop being grown. Crop evapotranspiration (ETc) is estimated from the product of potential evapotranspiration $\left(\mathrm{ET}_{0}\right)$ and crop water use coefficients. The AFSIRS model subdivides the crop root zone into irrigated and nonirrigated zones and maintains separate water budgets for both zones in order to simulate different types of irrigation systems, such as surface irrigation and subsurface irrigation.

The AFSIRS was used as a basis to estimate irrigation demand for the retrospective period using CMIP5 biascorrected downscaled daily $P$ and bias-corrected $\mathrm{ET}_{0}$ (using the three $\mathrm{ET}_{0}$ methods discussed above) and the land use from the calibrated INTB model. Crop coefficients $\left(K_{\mathrm{c}}\right)$ for estimating $\mathrm{ET}_{\mathrm{c}}$ were obtained from the calibrated INTB model database (Geurink and Basso, 2013) for all vegetative covers except row crops. The crop coefficient for row crops was estimated by the superposition of crop coefficients for tomato and strawberry (Dukes et al., 2012), the two dominant row crops in the region. The relative proportion of these two crops constituting the row crop land use were calculated based on water usage records for the region for 2011 (Jackson and Albritton, 2013). The root zone depth, field capacity, wilting point, and other information needed for the AFSIRS model were taken from the calibrated INTB model database. Groundwater pumping required to satisfy the AFSIRS estimated irrigation assumed $85 \%$ irrigation efficiency based on Irmak et al. (2011) and Jacobs and Dukes (2007), i.e.,

agricultural pumping $=$ irrigation demand $\times \frac{100 \%}{85 \%}$.

It should be noted that the AFSIRS model does not predict water demand for bed preparation, freeze protection, crop cooling requirements, or maintenance of irrigation systems. Thus the irrigation demand estimated for the retrospective period only includes crop water demand for evapotranspiration.

Boundary conditions. Lateral boundary conditions are required for aquifers in the model region. A repeating annual cycle of daily General Head Boundary (GHB) time series for the retrospective and future period IHM simulations was derived using the daily average of the historical daily GHB time 
Table 2. Future scenario summary.

\begin{tabular}{|c|c|c|c|c|}
\hline Scenario name & $\begin{array}{l}\text { Scenario } \\
\text { number }\end{array}$ & $\begin{array}{l}\text { Irrigation applied } \\
\text { to land surface }\end{array}$ & Agricultural pumping & Urban pumping \\
\hline No pumping & 1 & No & No & No \\
\hline No urban pumping & 2 & AFSIRS $^{\mathrm{a}}$ & $85 \%$ efficiency & No \\
\hline $\begin{array}{l}\text { No agricultural } \\
\text { pumping }\end{array}$ & 3 & No & No & $\begin{array}{l}\text { RETRO }{ }^{\mathrm{b}} \\
\text { CWF } 13 \mathrm{~mm} \mathrm{yr}^{-1} \\
\text { Total } 51 \mathrm{~mm} \mathrm{yr}^{-1}\end{array}$ \\
\hline Agricultural adaption & 4 & AFSIRS & $\begin{array}{l}85 \% \text { efficiency } \\
\text { Groundwater pumping } \\
\text { offset by } 6 \mathrm{~mm} \mathrm{yr}^{-1}\end{array}$ & $\begin{array}{l}\text { RETRO } \\
\text { CWF } 13 \mathrm{~mm} \mathrm{yr}^{-1} \\
\text { Total } 51 \mathrm{~mm} \mathrm{yr}^{-1}\end{array}$ \\
\hline Business as usual & 5 & AFSIRS & $85 \%$ efficiency & $\begin{array}{l}\text { RETRO } \\
\text { RETRO CWF } 13 \mathrm{~mm} \mathrm{yr}^{-1} \text {, } \\
\text { Total } 51 \mathrm{~mm} \mathrm{yr}^{-1}\end{array}$ \\
\hline $\begin{array}{l}\text { Increased agricultural } \\
\text { demand }\end{array}$ & 6 & $\begin{array}{l}\text { Increased by } \\
6 \mathrm{~mm} \mathrm{yr}^{-1}\end{array}$ & $85 \%$ efficiency & $\begin{array}{l}\text { RETRO } \\
\text { CWF } 13 \mathrm{~mm} \mathrm{yr}^{-1} \\
\text { Total } 51 \mathrm{~mm} \mathrm{yr}^{-1}\end{array}$ \\
\hline $\begin{array}{l}\text { Relaxed regulatory } \\
\text { requirements for } \\
\text { urban pumping }\end{array}$ & 7 & AFSIRS & $85 \%$ efficiency & $\begin{array}{l}\text { Increase CWF by } 6 \text { to } 19 \mathrm{~mm} \mathrm{yr}^{-1} \\
\text { CWF } 19 \mathrm{~mm} \mathrm{yr}^{-1} \\
\text { Total } 57 \mathrm{~mm} \mathrm{yr}^{-1}\end{array}$ \\
\hline $\begin{array}{l}\text { Relaxed regulatory } \\
\text { requirements for } \\
\text { all pumping }\end{array}$ & 8 & AFSIRS & $85 \%$ efficiency & $\begin{array}{l}\text { Increase all urban pumping by } 130 / 90 \\
\text { CWF } 19 \mathrm{~mm} \mathrm{yr}^{-1} \text {, } \\
\text { Total } 74 \mathrm{~mm} \mathrm{yr}^{-1}\end{array}$ \\
\hline
\end{tabular}

a AFSIRS: climate-driven irrigation water demand estimated by the AFSIRS model using GCMs. ${ }^{\mathrm{b}}$ RETRO: groundwater pumping in the future will be equal to retrospective groundwater pumping.

series spanning 2000 to 2006 . More details about the water withdrawals such as groundwater pumping, agricultural irrigation, CWFs, diversions, and boundary conditions during the calibration-verification period are described in Geurink and Basso (2013).

\subsection{Future water use scenarios}

In addition to warming temperatures and reduced precipitation due to climate change, increases in water withdrawal for agriculture and other human uses are potentially significant causes of declining river flow and groundwater levels (Alcamo et al., 2003; Vorosmarty et al., 2000). To assess the relative importance of climate change versus anthropogenic impact on the hydrologic system, ability to meet future water demand, and compliance with water resource regulations in the study region, eight future water use scenarios were developed (Table 2). These scenarios were based on discussions with Tampa Bay Water staff, projected increases in public water demand (Tampa Bay Water, 2013), projected changes in agricultural land use and agricultural irrigation demand (Florida Statewide Agricultural Irrigation Demand, 2017), potential agricultural adaption behaviors, and potential changes in groundwater regulations. For naming simplic- ity in the future scenarios agricultural and recreational water use categories are combined as agricultural demand and public supply; industrial/commercial and mining are combined as urban demand. The eight water use scenarios included (1) no groundwater pumping for agriculture or urban demand, (2) no urban groundwater pumping, (3) no agricultural groundwater pumping, (4) agricultural adaption (increased irrigation efficiency and/or use of reclaimed water), (5) business as usual, (6) increased agricultural demand, (7) relaxed regulatory requirements for CWF pumping (increased CWF pumping), and (8) relaxed regulatory requirements for all urban groundwater pumping (increased all urban pumping). Details regarding each of these water use scenarios are provided below.

The business as usual scenario (scenario 5 in Table 1) assumed no change in groundwater regulations. Thus the CWF pumping remained at the maximum permitted 90 MGD and all other urban pumping (industrial/commercial, mining, and other public water supply) remained at the average pumping rates used in the retrospective simulations. In this case all projected increases in future public water demand must be met by increased surface water extraction (if available), increased conservation, increased wastewater reuse, or de- 
salination capacity. For the business as usual scenario agricultural irrigation demand was estimated using the AFSIRS model and assuming $85 \%$ irrigation efficiency, as in the retrospective period simulations. However, the $P$ and $\mathrm{ET}_{0}$ used in the AFSIRS model were taken from the bias-corrected downscaled future GCM projections for both future 1 (20302060) and future 2 (2070-2100).

To more clearly separate the impact of human water use versus climate change on the hydrologic system, three extreme groundwater use reduction scenarios were developed. The no agricultural or urban pumping scenario (scenario 1) assumed that there was no groundwater pumping at all in the region. For this scenario agricultural and recreational pumping (and the associated irrigation of the land surface) as well as all urban pumping (including CWF, other public water supply, and industrial/mining) were set to zero. For the no urban pumping scenario (scenario 2) all urban pumping including CWF, other public water supplies, and industrial/mining was set to zero; however, agricultural pumping was assumed to be the same as the business as usual scenario. For the no agricultural pumping scenario (scenario 3) agricultural pumping and recreational pumping were set to zero; however, all urban pumping was assumed equal to the business as usual scenario.

The agricultural adaption scenario (scenario 4) assumed that increased irrigation efficiency and/or increased use of reclaimed water reduced groundwater pumping for agricultural and recreational irrigation by 40 MGD over climatedriven demand $\left(6 \mathrm{~mm} \mathrm{yr}^{-1}, \sim 25 \%\right)$. All urban pumping was assumed to be the same as the business as usual scenario. The increased agricultural demand scenario (scenario 6) assumed that irrigation demand increased by 40 MGD over climate-driven demand $\left(6 \mathrm{~mm} \mathrm{yr}^{-1}, \sim 25 \%\right)$ due to more intensive farming on existing agricultural lands (Florida Statewide Agricultural Irrigation Demand, 2017) and that all urban pumping was the same as the business as usual scenario. The relaxed regulatory requirements for CWF pumping (scenario 7) assumed an increase in CWF pumping up to $130 \mathrm{MGD}\left(19 \mathrm{~mm} \mathrm{yr}^{-1}, \sim 44 \%\right)$ from the current $90 \mathrm{MGD}$ $\left(13 \mathrm{~mm} \mathrm{yr}^{-1}\right)$ to help meet increased public water demand, and that agricultural and recreational pumping followed the business as usual scenario. The relaxed regulatory requirements for all urban pumping (scenario 8) assumed all urban pumping, including CWF pumping, other public water supply, industrial, and mining, increased by $44 \%$ (i.e., the same percentage increase as the CWF pumping for scenario 7) and that agricultural and recreational pumping followed the business as usual scenario. These water use scenarios consist of projected agricultural and urban groundwater pumping volumes that represent $0 \%$ to $27 \%$ of historic $P-\mathrm{ET}_{0}$.

It should be noted that land use change was not considered in this study. This assumption is consistent with a regional planning strategy that promotes agricultural and urban intensification on existing lands, along with protection of existing conservation lands, wetlands and water supplies
(Barnett et al., 2007). This assumption is also consistent with the Florida Statewide Agricultural Irrigation Demand (2017) that projects a $2 \%$ decline in agricultural land area between 2015 and 2040, but an $8.5 \%$ increase in agricultural water use as a net result of agricultural intensification and increased conservation. Future work will build on this study to evaluate land use change scenarios.

\subsection{Statistical analysis}

Variance-based sensitivity analysis is a global sensitivity analysis (GSA) method (Saltelli et al., 2008, 2010) used to apportion the total model output variance simultaneously onto all the varying input factors, and thus is preferred over the local, one factor at a time, sensitivity analyses (Homma and Saltelli, 1996; Saltelli, 1999). In this research the sensitivity of projected changes between future and retrospective mean monthly streamflow and groundwater levels was evaluated using the variance-based GSA method described in S. Chang et al. (2016).

Using the variance-based GSA method, the variance-based first-order effect is expressed as

$V_{X_{i}}\left(E_{X_{\sim i}}\left(Y \mid X_{i}\right)\right)$,

where $V$ is the scalar model output (i.e., change in mean monthly streamflow or groundwater level), and $X_{i}$ are the factors causing variation in the model output (i.e., choice of $\mathrm{GCM}, \mathrm{ET}_{0}$ method, and water use scenario). The expectation operator $E_{X_{\sim i}}\left(Y \mid X_{i}\right)$ indicates that the mean of $Y$ is taken over all possible values of $X$ except $X_{i}$ (i.e., $X_{\sim i}$ ) while keeping $X_{i}$ fixed. The variance, $V_{X_{i}}$, is then taken of this quantity over all possible values of $X_{i}$. The first-order sensitivity coefficient is

$S_{i}=\frac{V_{X_{i}}\left(E_{X_{\sim i}}(Y \mid X)\right)}{V(Y)}$,

where $V(Y)$ is the total variance of $Y$ over all $X_{i} . S_{i}$ is a normalized index varying between 0 and 1 , because $V_{X_{i}}\left(E_{X_{\sim i}}\left(Y \mid X_{i}\right)\right)$ varies between 0 and $V(Y)$ according to the identity (Mood et al., 1974):

$V_{X_{i}}\left(E_{X_{\sim i}}\left(Y \mid X_{i}\right)\right)+E_{X_{i}}\left(V_{X_{\sim i}}\left(Y \mid X_{i}\right)\right)=V(Y)$.

The first-order sensitivities of future changes in mean seasonal streamflow and groundwater level to the choice of $\mathrm{GCM}, \mathrm{ET}_{0}$ estimation method, and water use scenario were calculated over the full ensemble of eight GCMs, three $\mathrm{ET}_{0}$ methods, and eight water use scenarios (192 samples) for each future period in order to evaluate the relative contributions of each of these factors to the variation among projections of future changes.

In addition to variance-based GSA, differences in future changes of mean projected streamflow and groundwater level across GCMs and across future water use scenarios were evaluated for statistical significance using Tukey's HSD 
Table 3. The first-order sensitivity index of change in streamflow (future-retrospective period).

\begin{tabular}{llcccc}
\hline River gage & Season & Period & GCM & ET $_{0}$ & Water use scenario \\
\hline Hillsborough & Wet season & $2030-2060$ & 0.944 & 0.002 & 0.016 \\
& & $2070-2100$ & 0.940 & 0.041 & 0.006 \\
\cline { 2 - 6 } & \multirow{2}{*}{ Dry season } & $2030-2060$ & 0.948 & 0.012 & 0.029 \\
& & $2070-2100$ & 0.961 & 0.001 & 0.018 \\
\hline \multirow{2}{*}{ Alafia } & \multirow{2}{*}{ Wet season } & $2030-2060$ & 0.928 & 0.010 & 0.031 \\
& & $2070-2100$ & 0.952 & 0.021 & 0.012 \\
\cline { 2 - 6 } & \multirow{2}{*}{ Dry season } & $2030-2060$ & 0.876 & 0.012 & 0.072 \\
& & $2070-2100$ & 0.927 & 0.001 & 0.068 \\
\hline
\end{tabular}

Table 4. The first-order sensitivity index of change in groundwater level (future-retrospective period).

\begin{tabular}{lllllc}
\hline Monitoring well & Season & Period & GCM & ET $_{0}$ & Water use scenario \\
\hline \multirow{2}{*}{ NWH-RMP-08s } & Wet season & $2030-2060$ & 0.442 & 0.005 & 0.501 \\
& & $2070-2100$ & 0.576 & 0.004 & 0.278 \\
\cline { 2 - 6 } & Dry season & $2030-2060$ & 0.475 & 0.007 & 0.435 \\
& & $2070-2100$ & 0.550 & 0.002 & 0.288 \\
\hline \multirow{2}{*}{ CBR-SERW-s } & Wet season & $2030-2060$ & 0.656 & 0.000 & 0.214 \\
& & $2070-2100$ & 0.755 & 0.002 & 0.143 \\
\cline { 2 - 6 } & \multirow{2}{*}{ Dry season } & $2030-2060$ & 0.639 & 0.001 & 0.221 \\
& & $2070-2100$ & 0.747 & 0.002 & 0.146 \\
\hline \multirow{2}{*}{ STK-STARKEY-20s } & Wet season & $2030-2060$ & 0.604 & 0.000 & 0.325 \\
& & $2070-2100$ & 0.718 & 0.004 & 0.198 \\
\cline { 2 - 6 } & \multirow{2}{*}{ Dry season } & $2030-2060$ & 0.584 & 0.002 & 0.330 \\
& & $2070-2100$ & 0.707 & 0.001 & 0.200 \\
\hline
\end{tabular}

(honest significant difference) test (Zieyel, 1988), which is a single-step multiple statistical test (pairwise comparison). The two-sample $t$ test was used to test for significant differences between mean projected streamflow and groundwater levels resulting from future climate/water use scenarios and mean retrospective streamflow and groundwater level using the business as usual water use scenario.

\section{Results and discussion}

\subsection{Global sensitivity analysis of projected changes}

The variance-based global sensitivity analysis was conducted for both the wet season (June-September) and the dry season (October-May) to evaluate the relative variation of projected changes in hydrologic response attributed to the choice of GCM, choice of water use scenario, and choice of $\mathrm{ET}_{0}$ method. Tables 3 and 4 show the first-order sensitivity indices of changes in future streamflow and groundwater level (defined as future average seasonal streamflow, retrospective average seasonal streamflow and future average sea- sonal groundwater level, and retrospective average seasonal groundwater level, respectively).

Change in streamflow was much more sensitive to choice of GCM than to choice of $\mathrm{ET}_{0}$ method or water use scenario for all river gages, both seasons, and both future periods (Table 3). For example, $94.4 \%$ of the variance of the change in wet season Hillsborough River streamflow in the future 1 period (2030-2060) is attributed to differences among GCMs, $0.2 \%$ of the variance is attributed to differences among the $\mathrm{ET}_{0}$ method, and $1.6 \%$ of the variance is caused by the water use scenario, respectively (top row of Table 3). Similarly, projected changes in groundwater level were generally more sensitive to the choice of GCM for all monitoring wells and both seasons. However, unlike the projected changes in streamflow, changes in groundwater level were also quite sensitive to the choice of water use scenario (Table 4). The higher sensitivity of groundwater level to groundwater pumping is expected since the monitoring wells are intentionally located near the consolidated well fields (locations of major groundwater pumping) to detect and mitigate localized impacts of water supply pumping on nearby wetlands. On the other hand, the stream gages are located further 

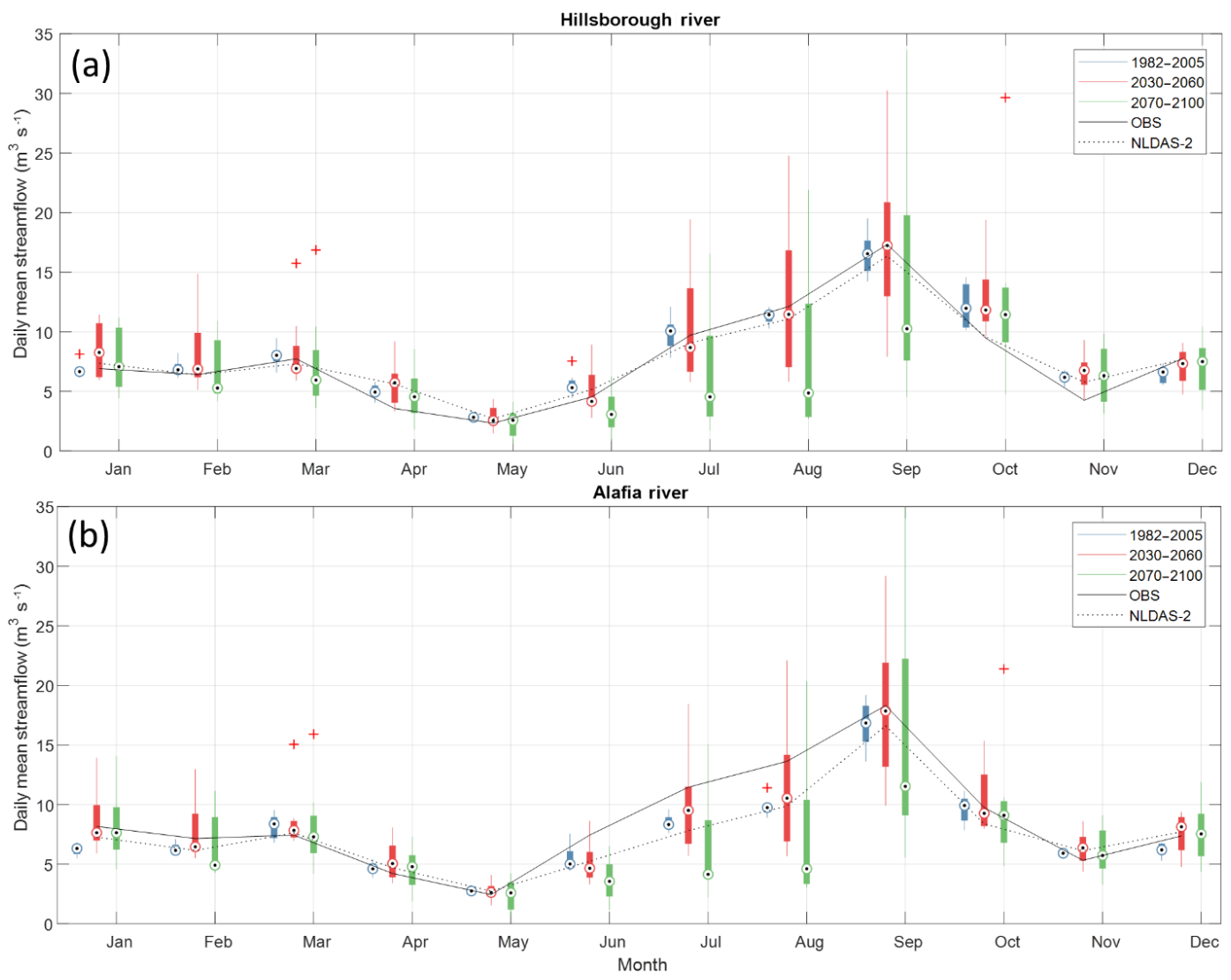

Figure 2. Mean monthly streamflow for the Hillsborough River (a) and Alafia River (b) for business as usual scenario water use and the Hargreaves $\mathrm{ET}_{0}$ method. Boxplots indicate the range of prediction over the eight GCMs.

from the consolidated well fields and accumulate flow from a large area of the model domain. The first-order sensitivity index of groundwater level to water use scenario decreased in future period 2 (2070-2100) over future period 1 (20302060), due to the increased variability of GCM precipitation projections in future $2(2070-2100)$ versus future 1 (20302060).

As mentioned previously, S. Chang et al. (2016) evaluated projected changes in $P-\mathrm{ET}_{0}$ over the continental USA using nine GCMs, $10 \mathrm{ET}_{0}$ estimation methods, and three RCP scenarios, and found that for the southeastern USA the choice of GCM and $\mathrm{ET}_{0}$ method had approximately equal influence on changes in future $P-\mathrm{ET}_{0}$ throughout most of the year. Because this study eliminated several $\mathrm{ET}_{0}$ estimation methods that produced unreasonably high and low historic $\mathrm{ET}_{0}$ estimates for the study region using the NLDAS-2 data, the first-order sensitivity index for $\mathrm{ET}_{0}$ is significantly lower in this study than in their results. It should be noted that these results do not indicate that the choice of reference ET estimation method does not affect the change in streamflow or groundwater, only that the choice of reference ET estimation method is much less influential than the choice of GCM or choice of water use scenario.

\subsection{Projections of streamflow}

The INTB was run to compare retrospective hydrologic response to historical observations and model predictions generated with the calibrated model using NLDAS-2 data, as well as to future hydrologic response as a result of alternative GCMs, $\mathrm{ET}_{0}$ methods, and water use scenarios. Figure 2 shows observed, NLDAS-2, and retrospective mean monthly streamflow for the Hillsborough River (Fig. 2a) and Alafia River (Fig. 2b), as well as future mean monthly streamflow in future $1(2030-2060)$ and future $2(2070-2100)$ for the business as usual water use scenario using the Hargreaves $\mathrm{ET}_{0}$ method originally used to calibrate the INTB model. The boxplots represent the range of mean monthly streamflow projections over eight GCMs for the business as usual water use scenario. Retrospective GCMs (blue boxplots) reproduced mean streamflow simulated using NLDAS-2 data quite closely for both river gages, with relatively small variation among GCMs. In the dry season (October-May) future 1 (red boxplots) and future 2 (green boxplots) business as usual mean monthly streamflow values over the eight GCMs (red boxplots) also showed relatively small differences with the retrospective predictions, but larger variation across GCMs. However, in the wet season (June through September) future 

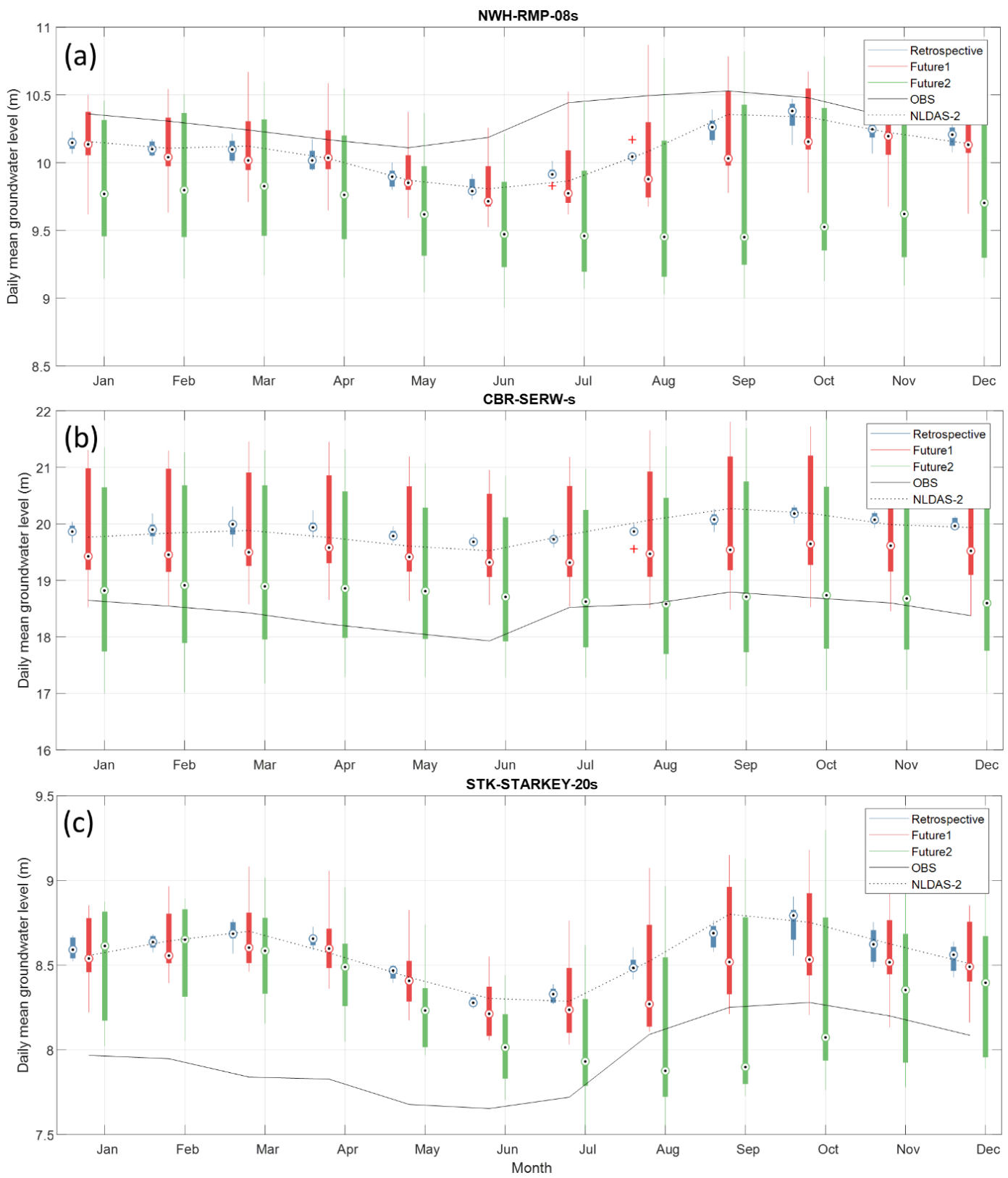

Figure 3. Mean monthly groundwater level for the NWH-RMP-08s (a), CBR-SERW-s (b) and STK-STARKEY-20s (c) for the business as usual water use scenario and the Hargreaves $\mathrm{ET}_{0}$ method. Boxplots indicate the range of prediction over the eight GCMs.

mean monthly streamflows for the business as usual scenario were lower than retrospective, especially in future 2 (20702100), and showed much larger variability across GCMs.

\subsection{Projections of groundwater level}

Figure 3 shows observed, NLDAS-2 predicted, and retrospective mean monthly groundwater level for the NWHRMP-08s (Fig. 3a), CBR-SERW-s (Fig. 3b), and STKSTARKEY-20s wells (Fig. 3c), as well as future mean monthly groundwater level in future 1 (2030-2060) and future 2 (2070-2100) for the business as usual water use sce- nario and the Hargreaves $\mathrm{ET}_{0}$ method. Groundwater levels projected by retrospective GCMs showed relatively small variation across GCMs and were very similar to groundwater levels simulated using the historic NLDAS-2 data for all three wells. Although observed seasonal patterns were reproduced accurately for all wells during the retrospective period, NWH-RMP-08s retrospective groundwater level predictions were lower than observed groundwater levels throughout the year (Fig. 3a). In contrast, all CBR-SERW-s and STKSTARKEY-20s retrospective groundwater lever predictions were higher than observed groundwater levels throughout 

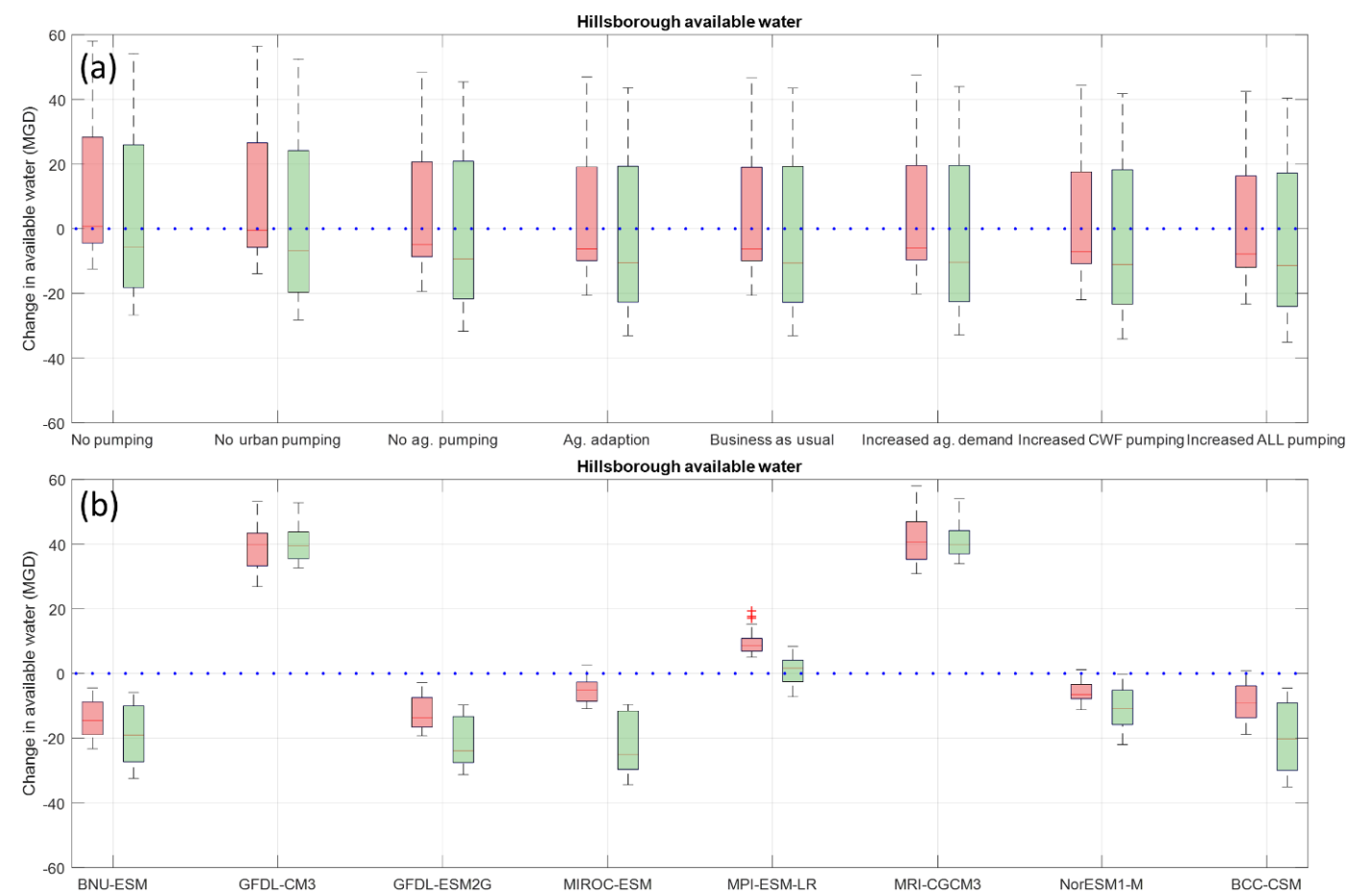

Figure 4. The change in the amount of available water that can be withdrawn from the Hillsborough River by (a) different water use scenarios over GCM and $\mathrm{ET}_{0}$ methods and by (b) different GCMs over water use scenarios and $\mathrm{ET}_{0}$ methods.

the year (Fig. $3 b$ and c). These deviations (which are generally less than $0.5 \mathrm{~m}$ ) are consistent with deviations between the observed data and groundwater levels simulated by the original calibrated model using the locally observed point weather data (Geurink and Basso, 2013). The mean groundwater levels averaged over GCMs for the future period 1 (2030-2060) business as usual scenario were similar to, or slightly lower than, the mean retrospective groundwater levels; however, the mean groundwater levels for future 2 (2070-2100) were significantly lower than mean groundwater levels in the retrospective period, especially in the wet season for all wells. Similar to the streamflow results variability in projected groundwater levels among GCMs was larger in future 2 (2070-2100) than in future 1 (2030-2060).

\subsection{Changes in future surface-water availability for public supply}

Tampa Bay Water operates surface-water pumps on the Hillsborough and Alafia rivers to help meet public water demand. The volume of flow permitted for extraction varies daily based on maintaining sufficient in-stream flows and spring flows to protect aquatic ecosystems. In this study, the amount of water that could be withdrawn for public water supply, while meeting current environmental regulations, was analyzed to evaluate projected changes in future water availability for different GCMs and water use scenarios. Boxplots in Fig. 4a show the variation in the projected change in the mean available water that can be withdrawn from the Hillsborough River (the mean available water that can be withdrawn for future streamflow - the mean available water that can be withdrawn for retrospective streamflow) over all GCMs and all $\mathrm{ET}_{0}$ methods for each water use scenario. The boxplots show large variations due to large differences in future streamflow projections. All boxplots encompass both positive and negative changes for both future periods, but indicate generally lower water availability in future $2(2070-2100)$ than future 1 (2030-2060). Figure $4 \mathrm{~b}$ compares the change in the projected mean available water that can be withdrawn from the Hillsborough River over water use scenarios and $\mathrm{ET}_{0}$ methods for each GCM. While there is some variation across water use scenarios and $\mathrm{ET}_{0}$ methods, Fig. $4 \mathrm{~b}$ clearly shows that projected changes in future surface water availability depend strongly on choice of GCM, with five GCMs showing less surface water availability in the future regardless of water use scenario. Plots for the Alafia River show very similar behavior by both water use scenario and GCM (Fig. S1 in the Supplement).

The differences between the mean projected changes in available water that can be withdrawn from the Hillsborough and Alafia rivers for individual water use scenarios over GCMs and $\mathrm{ET}_{0}$ methods (left columns in Table 5), and for individual GCMs over water use scenarios and $\mathrm{ET}_{0}$ methods (right columns in Table 5), were evaluated for statistical significance using Tukey's HSD (honest significant difference) test. The HSD test confirmed that none of the differences in 
Table 5. The results of Tukey's HSD test of mean change in the amount of available water (MGD) that can be withdrawn from the Hillsborough River or Alafia River for each water use scenario over GCM and $\mathrm{ET}_{0}$ methods, or for each GCM over water use scenario and $\mathrm{ET}_{0}$ method (comparison of all possible pairs of means).

\begin{tabular}{|c|c|c|c|c|c|c|c|c|c|}
\hline \multirow{2}{*}{$\begin{array}{l}\text { By human water } \\
\text { use scenario }\end{array}$} & \multicolumn{2}{|c|}{ Hillsborough } & \multicolumn{2}{|c|}{ Alafia } & \multirow[t]{2}{*}{ By GCM } & \multicolumn{2}{|c|}{ Hillsborough } & \multicolumn{2}{|c|}{ Alafia } \\
\hline & $\begin{array}{r}2030- \\
2060 \\
\text { mean }\end{array}$ & $\begin{array}{r}2070- \\
2100 \\
\text { mean }\end{array}$ & $\begin{array}{l}2030- \\
2060 \\
\text { mean }\end{array}$ & $\begin{array}{r}2070- \\
2100 \\
\text { mean }\end{array}$ & & $\begin{array}{l}2030- \\
2060 \\
\text { mean }\end{array}$ & $\begin{array}{l}2070- \\
2100 \\
\text { mean }\end{array}$ & $\begin{array}{l}2030- \\
2060 \\
\text { mean }\end{array}$ & $\begin{array}{l}2070 \\
2100 \\
\text { mean }\end{array}$ \\
\hline No pumping & $11.63 \mathrm{a}$ & $3.88 \mathrm{a}$ & $4.89 \mathrm{a}^{*}$ & $2.28 \mathrm{a}$ & BNU-ESM & $-14.03 \mathrm{e}^{*}$ & $-18.76 \mathrm{~d}^{*}$ & $-4.25 \mathrm{~d}^{*}$ & $-5.89 \mathrm{c}^{*}$ \\
\hline No urban pumping & $10.10 \mathrm{a}$ & $2.61 \mathrm{a}$ & $4.00 \mathrm{a}^{*}$ & $1.45 \mathrm{a}$ & GFDL-CM3 & $39.20 a^{*}$ & $40.27 \mathrm{a}^{*}$ & $8.16 \mathrm{a}^{*}$ & $9.11 \mathrm{a}^{*}$ \\
\hline No agricultural pumping & $5.57 \mathrm{a}$ & $-1.21 \mathrm{a}$ & $1.48 \mathrm{a}$ & $-0.99 a$ & GFDL-ESM2G & $-12.24 \mathrm{de}^{*}$ & $-21.68 \mathrm{~d}^{*}$ & $-1.84 \mathrm{~cd}$ & $-5.70 \mathrm{c}^{*}$ \\
\hline Agricultural adaption & $4.22 \mathrm{a}$ & $-2.54 \mathrm{a}$ & $0.85 \mathrm{ab}$ & $-1.60 \mathrm{a}$ & MIROC-ESM2G & $-5.01 \mathrm{c}$ & $-22.31 \mathrm{~d}^{*}$ & $-0.09 \mathrm{c}$ & $-6.26 c^{*}$ \\
\hline Business as usual & $4.16 \mathrm{a}$ & $-2.59 \mathrm{a}$ & $0.82 \mathrm{ab}$ & $-1.63 \mathrm{a}$ & MPI-ESM-LR & $9.71 b^{*}$ & $1.07 \mathrm{~b}$ & $2.01 \mathrm{~b}$ & $-0.56 \mathrm{~b}$ \\
\hline Increased agricultural demand & $4.56 \mathrm{a}$ & $-2.27 \mathrm{a}$ & $1.00 \mathrm{ab}$ & $-1.47 \mathrm{a}$ & MRI-CGCM3 & $41.64 a^{*}$ & $41.34 \mathrm{a}^{*}$ & $10.64 a^{*}$ & $10.46 a^{*}$ \\
\hline Increased CWF pumping & $2.90 \mathrm{a}$ & $-3.66 \mathrm{a}$ & $0.81 \mathrm{ab}$ & $-1.64 \mathrm{a}$ & NorESM1-M & $-5.58 \mathrm{c}$ & $-10.71 c^{*}$ & $0.78 \mathrm{bc}$ & $-2.21 \mathrm{c}^{*}$ \\
\hline Increased all pumping & $1.72 \mathrm{a}$ & $-4.65 \mathrm{a}$ & $-0.43 b$ & $-2.73 \mathrm{a}$ & BCC-CSM & $-8.84 \mathrm{~cd}^{*}$ & $-19.67 \mathrm{~d}^{*}$ & $-1.98 \mathrm{~cd}$ & $-5.28 c^{*}$ \\
\hline
\end{tabular}

Means with different subscripts were significantly different in Tukey's HSD test.

* The results were significantly different than retrospective BAU by a two-sample $t$ test at the 0.05 significance level.

the mean projected change in available water for different water use scenarios shown in Fig. 3a were statistically significant for the Hillsborough River for either future period (in Table 5 scenarios with the same alphabetic subscripts are not statistically significantly different). For the Alafia River the mean projected changes in available water for the extreme groundwater pumping reduction scenario was statistically significantly different from the other water use scenarios in future 1 (2030-2060), but no statistically significant changes were detected in future $2(2070-2100)$. These results imply that due to the large variations in climate projections produced by different GCMs, differences in mean projected changes in streamflow projections due to differences water use scenarios and $\mathrm{ET}_{0}$ methods cannot be reliably predicted by averaging over GCMs.

On the other hand, many of the differences between mean projected changes in available water that can be withdrawn from the Hillsborough and Alafia rivers for individual GCMs over water use scenarios were statistically significant for both future periods (i.e., many of the GCMs on the right side of Table 5 have different alphabetic subscripts). Two GCMs show a distinct increase in water availability from these rivers for public supply (GFDL-CM3 and MRI-CGCM3); however, most GCMs show a decrease in water availability (BNU-ESM, GFDL-ESM2G, MIROC-ESM, NorESM1-M, and BCC-CSM). These results underscore the fact that differences in projections of future availability of water from these rivers for public supply are driven more strongly by differences in climate models than differences in future human water use scenarios or $\mathrm{ET}_{0}$ methods. Furthermore, manipulating groundwater use to change the amount of available surface water has a very small effect for a given climate. These results are similar to previous studies (Bosshard et al., 2013; Forzieri et al., 2014; Guimberteau et al., 2013; Harding et al., 2012; Kay and Davies, 2008) that showed climate models are a large source of uncertainty for climate-impact projections because of the divergence of GCM projections.

In addition to the HSD test, the two-sample $t$ test was conducted to evaluate the statistical significance of differences between the mean available water that can be withdrawn for the retrospective period and the mean available water that can be withdrawn for each future water use scenario calculated over all GCMs and $\mathrm{ET}_{0}$ methods. The two-sample $t$ test indicated that, at the 0.05 significance level, none of the future scenarios were statistically significantly different from the retrospective business as usual scenario for the Hillsborough River. For the Alafia River only the no pumping and no urban pumping scenarios in future 1 (2030-2060) showed significant differences from the retrospective scenario in the available water that can be withdrawn from the Alafia River (marked as * in the left-hand columns of Table 5). In contrast most GCMs projected significantly different mean available water in both future periods compared to the retrospective period when averaged over water use scenarios (marked as * in the right-hand columns of Table 5).

The results that future streamflow projections are relatively insensitive to water use scenarios are contrary to that of Dale et al. (2015). They used historical streamflow and climate data to evaluate the impacts of anthropogenic change on streamflow and found that for an irrigation-intensive watershed located in an area with hot summers and limited precipitation (northern central Oklahoma, USA) irrigation from groundwater pumping increased antecedent soil moisture and played an equally important role in streamflow variability as climate change. These differences are likely due to that fact that the region studied here is wetter than their study region, the aquifer underlying the study region is large and productive, and land use changes were not considered in this study. 

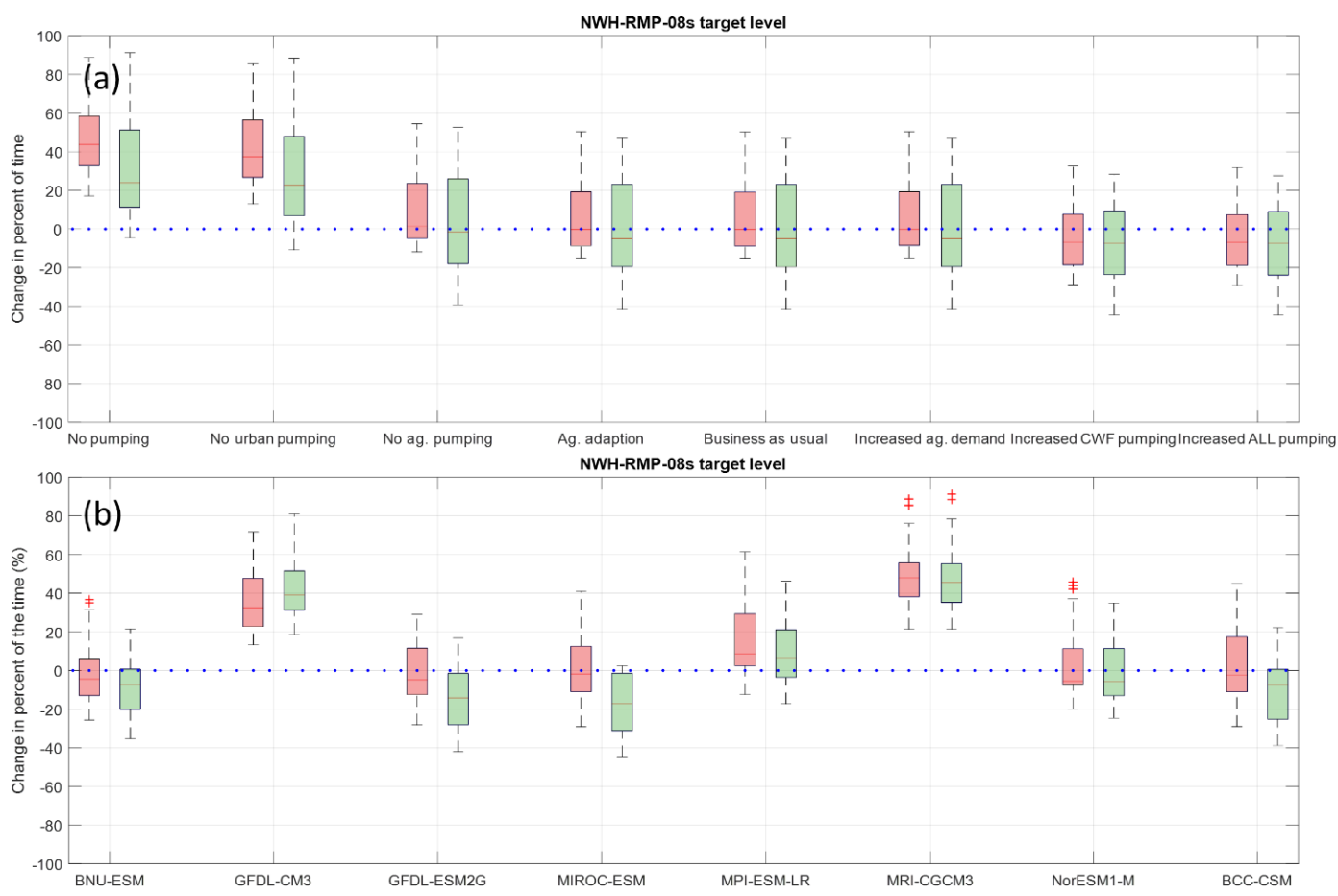

Figure 5. The change in the percent of the time that groundwater level is above the target level for NWH-RMP-08s well by (a) different water use scenarios over GCMs and $\mathrm{ET}_{0}$ methods and by (b) different GCMs over water use scenarios and $\mathrm{ET}_{0}$ methods.

\subsection{Changes in compliance with groundwater level regulations}

Groundwater pumping for water supply in the Tampa Bay region is regulated to maintain groundwater levels that promote environmental protection by preventing dewatering of lakes and wetlands near well fields. The relative importance of water use scenario and GCM selection on the change in percent of time that future groundwater levels were above the target levels (the percent of the time that groundwater level is above the target level for future scenario - the percent of the time that groundwater level is above the target level for retrospective scenario) was evaluated for three monitoring wells. Boxplots in Fig. 5a show the change in percent of the time that groundwater level was above the target level in the dry season (October-May) for the NWH-RMP-08s well over all GCMs for each water use scenario and $\mathrm{ET}_{0}$ methods. Tukey's HSD test showed that the two most extreme water use reduction scenarios, i.e., the no pumping scenario and the no urban pumping scenario, showed a statistically significant higher percent of time that groundwater is above the target level in future 1 (2030-2060) compared to the other future water use scenarios for the NWH-RMP-08s well (Table 6). Furthermore the $t$ test showed a statistically significant difference in the percent of time this well was above the target level in both futures 1 (2030-2060) and 2 (2070-2100) for these two scenarios compared to the retrospective scenario (marked with * in Table 6). Results for the other two wells were more ambiguous with Tukey's HSD test showing differences among several of the water use scenarios in future 1 for both wells, and among several water use scenarios in future 2 for STK-STARKEY-20s. The $t$ test for CBR-SERW-s and STK-STARKEY-20s showed statistically significant differences for the two most extreme water use reduction scenarios compared to the retrospective scenario both future 1 and future 2. Collectively these results confirm that future compliance with groundwater levels is sensitive to water use scenario. Scenarios that assume differences in CWF pumping predict statistically significant differences in future groundwater compliance when averaged over possible future climates and $\mathrm{ET}_{0}$ methods. On the other hand scenarios that assume similar differences in the magnitude of agricultural pumping generally do not show statistically significant differences in future groundwater compliance. These results are largely explained by the concentration of CWF wells near monitoring wells versus the distribution of agricultural pumping wells throughout the model domain.

Figure 5b indicates and Tukey's HSD test (Table 7) confirms that the mean change in percent of time that groundwater is above the target level in the monitoring wells was significantly different for many GCMs in both future periods for all three wells (Figs. 5 and S2-S3). Two "wet" GCMs (GFDL-CM3 and MRI-CGCM3) projected statistically significant increases in the mean percent of the time that groundwater is above the target level for both future periods compared to the retrospective period in all three wells when 
Table 6. The results of Tukey's HSD test of mean change in the percent of the time that groundwater level is above the target level for monitoring wells over all GCMs and $\mathrm{ET}_{0}$ methods for each water use scenario (comparison of all possible pairs of means).

\begin{tabular}{|c|c|c|c|c|c|c|}
\hline \multirow[t]{2}{*}{ By human water use scenario } & \multicolumn{2}{|c|}{ NWH-RMP-08s } & \multicolumn{2}{|c|}{ CBR-SERW-s } & \multicolumn{2}{|c|}{ STK-STARKEY-20s } \\
\hline & $\begin{array}{l}2030 \\
2060 \\
\text { mean }\end{array}$ & $\begin{array}{l}2070 \\
2100 \\
\text { mean }\end{array}$ & $\begin{array}{l}2030- \\
2060 \\
\text { mean }\end{array}$ & $\begin{array}{l}2070- \\
2100 \\
\text { mean }\end{array}$ & $\begin{array}{l}2030- \\
2060 \\
\text { mean }\end{array}$ & $\begin{array}{l}2070- \\
2100 \\
\text { mean }\end{array}$ \\
\hline No pumping & $46.04 \mathrm{a}^{*}$ & $32.21 b^{*}$ & $31.93 a^{*}$ & $22.79 a^{*}$ & $27.87 \mathrm{a}^{*}$ & $18.00 a^{*}$ \\
\hline No urban pumping & $41.17 \mathrm{a}^{*}$ & $28.36 \mathrm{a}^{*}$ & $31.40 \mathrm{ab}^{*}$ & $22.45 \mathrm{a}^{*}$ & $26.91 \mathrm{ab}^{*}$ & $17.22 \mathrm{ab}^{*}$ \\
\hline No agricultural pumping & $10.28 \mathrm{~b}$ & $3.69 \mathrm{~b}$ & $11.00 c^{*}$ & $7.21 \mathrm{a}$ & $3.92 \mathrm{va}^{*}$ & $-2.04 b c$ \\
\hline Agricultural adaption & $6.66 \mathrm{~b}$ & $0.88 \mathrm{~b}$ & $10.76 \mathrm{c}$ & $7.06 \mathrm{a}$ & $3.15 \mathrm{ab}$ & $-2.79 c$ \\
\hline Business as usual & $6.55 \mathrm{~b}$ & $0.81 \mathrm{~b}$ & $10.73 \mathrm{c}$ & $7.04 \mathrm{a}$ & $3.12 \mathrm{ab}$ & $-2.80 \mathrm{c}$ \\
\hline Increased agricultural demand & $6.70 \mathrm{~b}$ & $0.89 \mathrm{~b}$ & $11.14 b^{*}$ & $7.32 \mathrm{a}$ & $3.21 \mathrm{ab}$ & $-2.73 c$ \\
\hline Increased CWF pumping & $-4.25 b$ & $-7.81 b$ & $5.23 \mathrm{c}$ & $3.01 \mathrm{a}$ & $-4.31 b$ & $-9.05 c$ \\
\hline Increased all pumping & $-4.64 b$ & $-8.13 b$ & $4.08 \mathrm{c}$ & $1.93 \mathrm{a}$ & $-6.07 b$ & $-10.52 c^{*}$ \\
\hline
\end{tabular}

Means with different subscripts were significantly different in Tukey's HSD test.

* The results were significantly different than retrospective BAU by a two-sample $t$ test at the 0.05 significance level.

Table 7. The results of Tukey's HSD test of mean change in percent of the time that groundwater level is above the target level for monitoring wells over all water use scenarios and $\mathrm{ET}_{0}$ methods for each GCM (comparison of all possible pairs of means).

\begin{tabular}{|c|c|c|c|c|c|c|}
\hline \multirow[t]{2}{*}{ By GCM } & \multicolumn{2}{|c|}{ NWH-RMP-08s } & \multicolumn{2}{|c|}{ CBR-SERW-s } & \multicolumn{2}{|c|}{ STK-STARKEY-20s } \\
\hline & $\begin{array}{l}2030- \\
2060 \\
\text { mean }\end{array}$ & $\begin{array}{l}2070- \\
2100 \\
\text { mean }\end{array}$ & $\begin{array}{l}2030- \\
2060 \\
\text { mean }\end{array}$ & $\begin{array}{l}2070- \\
2100 \\
\text { mean }\end{array}$ & $\begin{array}{l}2030- \\
2060 \\
\text { mean }\end{array}$ & $\begin{array}{l}2070- \\
2100 \\
\text { mean }\end{array}$ \\
\hline BNU-ESM & $-6.39 c$ & $-18.59 b c^{*}$ & $-12.08 \mathrm{c}^{*}$ & $-16.66 c^{*}$ & $-12.55 \mathrm{~d}$ & -18.30 def* $^{*}$ \\
\hline GFDL-CM3 & $32.35 \mathrm{bc}^{*}$ & $39.44 \mathrm{a}^{*}$ & $48.12 \mathrm{bc}^{*}$ & $56.39 \mathrm{a}^{*}$ & $19.56 b c^{*}$ & $24.50 \mathrm{bc}^{*}$ \\
\hline GFDL-ESM2G & $-3.22 b c$ & $-18.93 b c$ & $-7.58 \mathrm{c}$ & $-22.84 c^{*}$ & $-12.96 \mathrm{~d}^{*}$ & $-16.40 \mathrm{cde}^{*}$ \\
\hline MIROC-ESM & $-4.83 c$ & $-35.79 \mathrm{c}^{*}$ & $4.97 \mathrm{c}$ & $-15.52 c^{*}$ & $-12.96 \mathrm{~d}^{*}$ & $-39.01 \mathrm{f}^{*}$ \\
\hline MPI-ESM-LR & $11.26 \mathrm{abc}$ & $3.41 \mathrm{~b}$ & $29.83 b^{*}$ & $14.15 b^{*}$ & $12.02 \mathrm{abc}^{*}$ & $4.06 \mathrm{bc}$ \\
\hline MRI-CGCM3 & $41.27 \mathrm{a}^{*}$ & $39.67 a^{*}$ & $62.87 a^{*}$ & $56.38 \mathrm{a}^{*}$ & $34.45 \mathrm{a}^{*}$ & $26.16 a^{*}$ \\
\hline NorESM1-M & $3.84 \mathrm{bc}$ & $-3.47 b$ & $1.18 \mathrm{c}$ & $-8.40 \mathrm{c}$ & $2.31 \mathrm{bcd}$ & $0.17 \mathrm{~cd}$ \\
\hline BCC-CSM & $-2.38 \mathrm{bc}$ & $-25.30 b^{*}$ & $1.17 \mathrm{c}$ & $-12.51 c^{*}$ & $-11.45 \mathrm{~cd}$ & $-28.99 \mathrm{ef}^{*}$ \\
\hline
\end{tabular}

Means with different subscripts were significantly different in Tukey's HSD test.

* The results were significantly different than retrospective BAU by a two-sample $t$-test at the 0.05 significance level.

averaged over future water use scenario and $\mathrm{ET}_{0}$ method (Fig. 5b and marked as * in the Table 7). Three "drier" GCMs (BNU-ESM, MIROC-ESM and BCC-CSM) projected statistically significant decreases in percent of the time that groundwater level is above the target level compared to the retrospective period in future 2 (2070-2100) for all three wells. More GCMs showed significant differences in future period 2 (2070-2100) than in future period 1 (2030-2060) compared to the retrospective period because the differences among climate model projections increase in the later future. These results indicate that for drier future climate groundwater level regulations may be difficult to achieve regardless of groundwater pumping scenario, and thus may have to change with the changing climate.

\subsection{Ability to meet future water demand}

Future water demand projections for Tampa Bay Water indicate that even with active urban water conservation programs public water supply demand is expected to increase from approximately 220 MGD in 2010 to approximately 278 MGD in 2045 (Tampa Bay Water Water Demand Management Plan Final Report, 2013). At the present time the Tampa Bay water supply system includes 90 MGD groundwater pumping permitted for the CWF, a 25 MGD desalination plant and permitted water withdrawals from the Hillsborough and Alafia rivers that vary daily to maintain ecologically protective instream flows. Scenario discovery analysis (Tariq et al., 2017) was used to explore the ability of Tampa Bay Water to meet 2045 water demand while maintaining or improving existing levels of compliance with surface and groundwater regulations. 


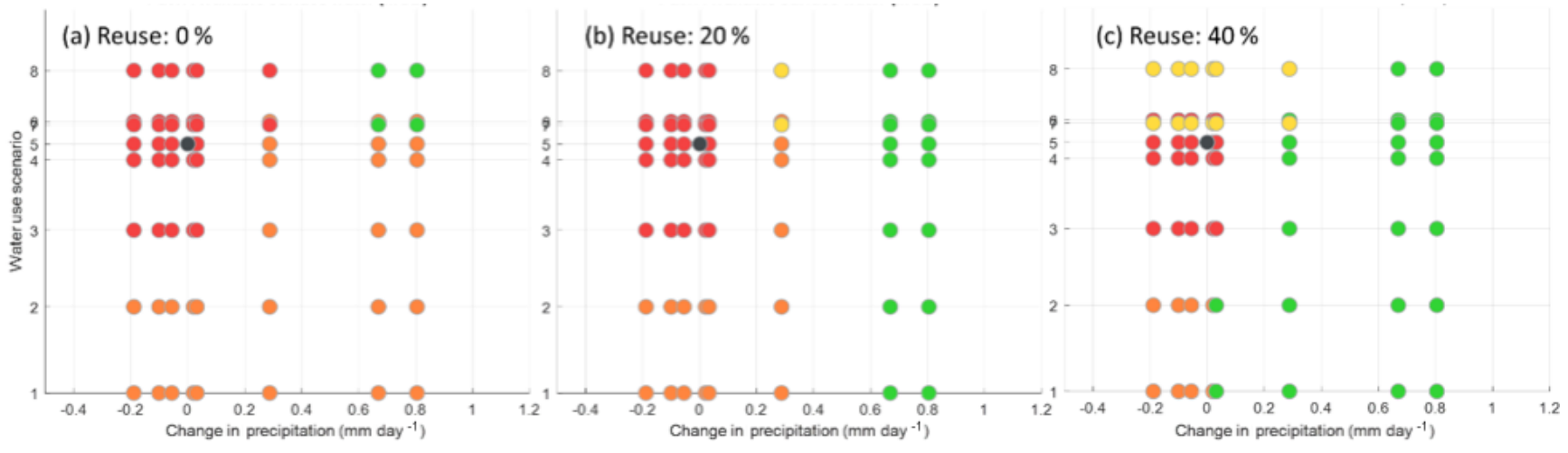

Figure 6. Scatterplot of futures in which Tampa Bay Water meets 2045 water demands and maintains or improves compliance with groundwater regulations in future 1 (2030-2060) assuming $0 \%, 20 \%$, and $40 \%$ of freshwater withdrawn are reclaimed and reused to satisfy urban demand. Green filled circles indicate futures that meet both 2045 water demand and maintain groundwater compliance levels at or above current conditions. Yellow filled circles indicate futures that meet 2045 water demand but decrease the level of groundwater compliance. Orange filled circles indicate futures that do not meet 2045 water demand but maintain groundwater compliance levels at or above current conditions. Red filled circles indicate futures that do not meet 2045 water demand and decrease the level of groundwater compliance. The black filled circle indicates the retrospective business as usual condition.

Figure 6 presents the results of the scenario discovery analyses that evaluates which climate and water use scenarios achieve these objectives in future 1 (2030-2060) using the Hargreaves $\mathrm{ET}_{0}$ method. In these analyses it was assumed that Tampa Bay Water's desalination capacity would remain at 25 MGD, surface water would be extracted at the maximum rate that complied with existing regulations, and $0 \%$ (current condition), $20 \%$, or $40 \%$ of Tampa Bay Water's public water supply (surface water, groundwater, and desalination) might be reclaimed and reused to satisfy public demand. The axes in Fig. 6 represent the two most important factors in the climate and water use scenarios that affect achievement of Tampa Bay Water's goals: mean change in precipitation projected by the different GCMs and volume of agricultural and urban groundwater pumping in the water use scenario. Green filled circles indicate futures that meet both 2045 water demand and maintain groundwater compliance levels at or above current conditions in future 1 (2030-2060). Yellow filled circles indicate futures that meet 2045 water demand but decrease the level of groundwater compliance. Orange filled circles indicate futures that do not meet 2045 water demand but maintain groundwater compliance levels at or above current conditions. Red filled circles indicate futures that do not meet 2045 water demand and decrease the level of groundwater compliance. The black filled circle indicates the retrospective business as usual condition.

Figure 6a shows that, without using reclaimed water to satisfy public water demand, only four scenarios are able to meet 2045 demand and maintain or improve existing levels of compliance with groundwater regulations (filled green circles in Fig. 6a). These four scenarios assume the two wettest future climates (projected by GFDL-CM3 and MRI-CGM3) will occur and permitted CWF pumping will increase from
90 to 130 MGD. No other climate-water use scenarios are able to meet 2045 demand without use of reclaimed water (there are no yellow filled circles in Fig. 6a). In fact a significant number of the scenarios, including many that assume the business as usual water use scenario, are not able to meet 2045 demand and also decrease compliance groundwater regulations (red filled circles in Fig. 6a).

Figure $6 \mathrm{~b}$ shows that $20 \%$ of freshwater withdrawn is reclaimed and used to satisfy public demand the two wettest future climates can meet 2045 demand and maintain or improve existing levels of compliance with groundwater regulations for all water use scenarios. However, no other scenarios are able to achieve both goals. If $40 \%$ of freshwater withdrawn is reclaimed and used to satisfy public demand more scenarios are able to achieve both goals. These scenarios include the climate scenarios that project that at least the existing average annual rainfall will occur in the future (i.e., projected change in average annual rainfall greater than or equal to zero). However, to meet both public water demand and maintain existing compliance with groundwater regulations, scenarios that predict the same rainfall as current climate require a complete switch of public water supply from groundwater to surface water sources (bottom two water use scenarios in Fig. 6). This would require Tampa Bay Water to significantly increase their surface water storage and treatment capacity and eliminates the use of their most inexpensive water source (groundwater). If groundwater regulations were relaxed, and $40 \%$ freshwater withdrawn in reclaimed, 2045 demand could be met under any climate scenario (yellow circles in Fig. 6c). It should be noted that the Regional Water Supply Planning (2016) reported that in 2015 only about $11.5 \%$ of total freshwater withdrawn was reused in Florida. Therefore reclaiming 
$20 \%-40 \%$ of freshwater withdrawn will be a significant investment.

\section{Conclusions}

It is important to evaluate possible changes in future streamflow and groundwater levels to evaluate risks in water resource management and planning. This study investigated potential future changes in hydrologic systems, ability to meet future water demand, and compliance with water resource regulation using eight GCMs, eight human water use scenarios, and three $\mathrm{ET}_{0}$ methods to drive an integrated hydrologic model developed for the Tampa Bay region. Variance-based sensitivity analysis showed that changes in projected streamflow were very sensitive to GCM selection, but relatively insensitive to $\mathrm{ET}_{0}$ method or water use scenario. Changes in projections of groundwater level were sensitive to both GCM and water use scenario, but relatively insensitive to $\mathrm{ET}_{0}$ method.

The eight GCMs projected diverse changes in streamflow and groundwater level, with most GCMs projecting statistically significant different future streamflow and groundwater levels than the current condition. Five of the eight GCMs projected a decrease in future streamflow and groundwater level in the INTB region regardless of water use scenario or ET method. None of the eight GCMs projected that 2045 water demand could be met under the business as usual water use scenario. Two GCMs (GFDL-CM3 and MRI-CGCM3) predicted increased streamflow and groundwater levels and an ability to meet 2045 projected water demand and maintain existing levels of compliance with groundwater standards if permitted CWF pumping were increased from the current 90 MGD to 130 MGD. The GCM that predicted that future annual average rainfall will be approximately equal to current rainfall met 2045 demand maintained existing levels of compliance with groundwater standards only for the water use scenarios that eliminated CWF pumping completely and reclaimed $40 \%$ of freshwater withdrawals.

These results suggest that it is more likely than not that climate change will reduce the availability of both surface and groundwater for public supply in the Tampa Bay region. Current regulations on water withdrawals (surface water withdrawal permit thresholds and target levels in monitoring wells near lakes and wetlands) may have to adapt to future climate conditions since only extreme changes in human water use (i.e., dramatic increases in use of reclaimed water and a complete switch from groundwater to surface water) may be able to maintain retrospective hydrologic regimes and associated aquatic ecosystems and meet human water demand in the future.

It should be noted that the findings of this study are limited by a few major assumptions. For example this study used only eight GCMs to project future climate which is a relatively small number. However, these eight GCMs spanned the range of cool to warm bias and wet to dry bias exhibited by 41 CMIP5 GCMs for the southeastern United States (Rupp, 2016). In addition land use change was not considered in this study. Instead we assumed the increases in agricultural and urban water demand were the result of intensification of water use on existing land uses. This assumption is consistent with a regional planning strategy that promotes agricultural and urban intensification on existing lands, along with protection of existing conservation lands, wetlands and water supplies (Barnett et al., 2007). However, future work should build on this study to evaluate the additional impacts of potential land use change scenarios (Gupta et al., 2015; Lin et al., 2015; Matheussen et al., 2000; Yan et al., 2013).

Data availability. The evaluated data and results for this study are not yet updated to DOI or URLs. We will update the data file and original codes used in this paper on the University of Florida Water Institute webpage (http://waterinstitute.ufl.edu, last access: 10 September 2018) or the Florida Water And Climate Alliance webpage (http://www.floridawca.org, last access: 10 September 2018).

Supplement. The supplement related to this article is available online at: https://doi.org/10.5194/hess-22-4793-2018-supplement.

Author contributions. SC: study conception and design, acquisition of data, hydrologic modeling, analysis and interpretation of data, drafting of manuscript, critical revision. WG: study conception and design, analysis and interpretation of data, drafting of manuscript, critical revision. JG: study conception and design, hydrologic modeling. NW: hydrologic modeling. TA: study conception and design, critical revision.

Competing interests. The authors declare that they have no conflict of interest.

Acknowledgements. This research was supported by Tampa Bay Water and the University of Florida Water Institute. We gratefully acknowledge the modeling groups participating in the Program for Climate Model Diagnosis and Inter-comparison (PCMDI) for their role in making the CMIP5 (Coupled Model Intercomparison Project) multi-model data set available.

Edited by: Greg Characklis

Reviewed by: three anonymous referees

\section{References}

Aalst, M. Van, Adger, N., Arent, D., Barnett, J., Betts, R., Bilir, E., Birkmann, J., Carmin, J., Chadee, D., Challinor, A., Chatterjee, M., Cramer, W., Davidson, D., Estrada, Y., Gattuso, J.- 
P., Hijioka, Y., Hoegh-Guldberg, O., Huang, H.-Q., Insarov, G., Jones, R., Kovats, S., Lankao, P. R., Larsen, J. N., Losada, I., Marengo, J., McLean, R., Mearns, L., Mechler, R., Morton, J., Niang, I., Oki, T., Olwoch, J. M., Opondo, M., Poloczanska, E., Pörtner, H.-O., Redsteer, M. H., Reisinger, A., Revi, A., Schmidt, D., Shaw, R., Solecki, W., Stone, D., Stone, J., Strzepek, K., Suarez, A., Tschakert, P., Valentini, R., Vicuna, S., Villamizar, A., Vincent, K., Warren, R., White, L., Wilbanks, T., Wong, P. P., and Yohe, G.: Climate Change 2014: Impacts, Adaptation, and Vulnerability, Assessment Report 5, 1-76, https://doi.org/10.1017/CBO9781107415379, 2014.

Abatzoglou, J. T. and Brown, T. J.: A comparison of statistical downscaling methods suited for wildfire applications, Int. J. Climatol., 32, 772-780, https://doi.org/10.1002/joc.2312, 2012.

Alcamo, J., Döll, P., Henrichs, T., Kaspar, F., Lehner, B., Rösch, T., and Siebert, S.: Development and testing of the WaterGAP 2 global model of water use and availability, Hydrolog. Sci. J., 48, 317-337, https://doi.org/10.1623/hysj.48.3.317.45290, 2003.

Allen, R. G., Pereira, L. S., Raes, D., and Smith, M.: Crop evapotranspiration - guidelines for computing crop water requirements, Food and Agriculture Organization, Rome, FAO Irrigation and drainage paper 56, 1998.

Barnett, J., Dobshinsky, A., Choi, B., Cunningham, A., Dickens, M., Driver, J., Fan, L., Garcia, J., Gibson, N., Graves, J., Henkel, M., Khedhri, S., Lai, J., Lally, J., Lewis, M., Massa, L., Melusky, A., and Ottoson, L.: An alternative future: Florida in the 21 st Century 20202040 2060, University of Central Florida, Orlando, Florida, 2007.

Bentsen, M., Bethke, I., Debernard, J. B., Iversen, T., Kirkevåg, A., Seland, Ø., Drange, H., Roelandt, C., Seierstad, I. A., Hoose, C., and Kristjánsson, J. E.: The Norwegian Earth System Model, NorESM1-M - Part 1: Description and basic evaluation of the physical climate, Geosci. Model Dev., 6, 687-720, https://doi.org/10.5194/gmd-6-687-2013, 2013.

Bicknell, B. R., Imhoff, J. C., Kittle, Jr., J. L., Jobes, T. H., and Donigian Jr., A. S.: Hydrological Simulation Program - Fortran: HSPF Version 12.2 User's Manual, Environmental Research Laboratory, U.S. Environmental Protection, 2005.

Block, K. and Mauritsen, T.: Forcing and feedback in the MPI-ESM-LR coupled model under abruptly quadrupled $\mathrm{CO}_{2}$, J. Adv. Model. Earth Syst., 5, 676-691, https://doi.org/10.1002/jame.20041, 2013.

Block, P. J., Souza Filho, F. A., Sun, L., and Kwon, H. H.: A streamflow forecasting framework using multiple climate and hydrological models, JAWRA Journal of the American Water Resources Association, 45, 828-843, https://doi.org/10.1111/j.1752-1688.2009.00327.x, 2009.

Boé, J., Terray, L., Habets, F., and Martin, E.: Statistical and dynamical downscaling of the Seine basin climate for hydro-meteorological studies, Int. J. Climatol., 27, 1643-1655, https://doi.org/10.1002/joc.1602, 2007.

Bosshard, T., Carambia, M., Goergen, K., Kotlarski, S., Krahe, P., Zappa, M., and Schär, C.: Quantifying uncertainty sources in an ensemble of hydrological climateimpact projections, Water Resour. Res., 49, 1523-1536, https://doi.org/10.1029/2011WR011533, 2013.

Chang, J., Zhang, H., Wang, Y., and Zhu, Y.: Assessing the impact of climate variability and human activities on stream- flow variation, Hydrol. Earth Syst. Sci., 20, 1547-1560, https://doi.org/10.5194/hess-20-1547-2016, 2016.

Chang, S.: Quantifying the relative uncertainties of changes in climate and water demand for water supply planning, $\mathrm{PhD}$ dissertation, University of Florida, Gainesville, Florida, USA, 2017.

Chang, S., Graham, W. D., Hwang, S., and Muñoz-Carpena, R.: Sensitivity of future continental United States water deficit projections to general circulation models, the evapotranspiration estimation method, and the greenhouse gas emission scenario, Hydrol. Earth Syst. Sci., 20, 3245-3261, https://doi.org/10.5194/hess-20-3245-2016, 2016.

Chen, J., Brissette, F. P., Chaumont, D., and Braun, M.: Finding appropriate bias correction methods in downscaling precipitation for hydrologic impact studies over North America, Water Resour. Res., 49, 4187-4205, https://doi.org/10.1002/wrcr.20331, 2013.

Dale, J., Zou, C. B., Andrews, W. J., Long, J. M., Liang, Y., and Qiao, L.: Climate, water use, and land surface transformation in an irrigation intensive watershed-Streamflow responses from 1950 through 2010, Agr. Water Manage., 160, 144-152, https://doi.org/10.1016/j.agwat.2015.07.007, 2015.

Déry, S. J., Hernández-Henríquez, M. A., Burford, J. E., and Wood, E. F.: Observational evidence of an intensifying hydrological cycle in northern Canada, Geophys. Res. Lett., 36, L13402, https://doi.org/10.1029/2009GL038852, 2009.

Diffenbaugh, N. S. and Field, C. B.: Changes in ecologically critical terrestrial climate conditions, Science, 341, 486-492, https://doi.org/10.1126/science.1237123, 2013.

Dukes, M. D., Zotarelli, L., Liu, G. D., and Simonne, E. H.: Principles and Practices of Irrigation Management for Vegetables, IFAS, University of Florida, 1-14, 2012.

Florida Statewide Agricultural Irrigation Demand: Estimated Agricultural Water Demand, 2015-2040, The Balmoral Group, Winter Park, Florida, 2017.

Forzieri, G., Feyen, L., Rojas, R., Flörke, M., Wimmer, F., and Bianchi, A.: Ensemble projections of future streamflow droughts in Europe, Hydrol. Earth Syst. Sci., 18, 85-108, https://doi.org/10.5194/hess-18-85-2014, 2014.

Georgakakos, A., Fleming, P., Dettinger, M., Peters-Lidard, C., Richmond, T., Reckhow, K., White, K., and Yates, D.: Ch. 3: Water Resources, in: Climate Change Impacts in the United States: The Third National Climate Assessment, edited by: Melillo, J. M., Richmond, T. (T. C.), and Yohe, G. W., U.S. Global Change Research Program, 69-112, https://doi.org/10.7930/J0G44N6T, 2014.

Geurink, J. S. and Basso, R.: Development, Calibration, and Evaluation of the Integrated Northern Tampa Bay Hydrologic Model, Tampa Bay Water/Southwest Florida Water Management District, Clearwater/Brooksville, Florida, 2013.

Ghosh, S. and Mujumdar, P. P.: Statistical downscaling of GCM simulations to streamflow using relevance vector machine, Adv. Water Resour., 31, 132-146, https://doi.org/10.1016/j.advwatres.2007.07.005, 2008.

Giorgi, F. and Mearns, L.: Calculation of average, uncertainty range, and reliability of regional climate changes from AOGCM simulations via the "reliability ensemble averaging"(REA) method, J. Climate, 15, 1141-1158, https://doi.org/10.1175/15200442(2002)015<1141:COAURA>2.0.CO;2, 2002.

Green, T. R., Taniguchi, M., Kooi, H., Gurdak, J. J., Allen, D. M., Hiscock, K. M., Treidel, H., and Aureli, A.: 
Beneath the surface of global change: Impacts of climate change on groundwater, J. Hydrol., 405, 532-560, https://doi.org/10.1016/j.jhydrol.2011.05.002, 2011.

Guimberteau, M., Ronchail, J., Espinoza, J. C., Lengaigne, M., Sultan, B., Polcher, J., Drapeau, G., Guyot, J.-L., Ducharne, A., and Ciais, P.: Future changes in precipitation and impacts on extreme streamflow over Amazonian sub-basins, Environ. Res. Lett., 8, 014035, https://doi.org/10.1088/1748-9326/8/1/014035, 2013.

Guo, H., Golaz, J.-C., Donner, L. J., Ginoux, P., and Hemler, R. S.: Multivariate Probability Density Functions with Dynamics in the GFDL Atmospheric General Circulation Model: Global Tests, J. Climate, 27, 2087-2108, https://doi.org/10.1175/JCLID-13-00347.1, 2014

Gupta, S. C., Kessler, A. C., Brown, M. K., and Zvomuya, F.: Climate and agricultural land use change impacts on streamflow in the upper midwestern United States, Water Resour. Res., 51, 5301-5317, https://doi.org/10.1002/2015WR017323, 2015.

Haddeland, I., Heinke, J., Biemans, H., Eisner, S., Flörke, M., Hanasaki, N., Konzmann, M., Ludwig, F., Masaki, Y., Schewe, J., Stacke, T., Tessler, Z. D., Wada, Y., and Wisser, D.: Global water resources affected by human interventions and climate change, P. Natl. Acad. Sci. USA, 111, 3251-3256, https://doi.org/10.1073/pnas.1222475110, 2014.

Harbaugh, A. W. and McDonald, M. G.: User's Documentation for MODFLOW-96, an update to the U.S. Geological Survey Modular Finite-Difference Ground-Water Flow Model, Open-File Report, U.S. Geological Survey, Open-File Report 96-485, 1996.

Harding, B. L., Wood, A. W., and Prairie, J. R.: The implications of climate change scenario selection for future streamflow projection in the Upper Colorado River Basin, Hydrol. Earth Syst. Sci., 16, 3989-4007, https://doi.org/10.5194/hess-16-3989-2012, 2012.

Hargreaves, G. H. and Allen, R. G.: History and Evaluation of Hargreaves Evapotranspiration Equation, J. Irrig. Drain. E.ASCE, 129, 53-63, https://doi.org/10.1061/(ASCE)07339437(2003)129:1(53), 2003

Hawkins, E. and Sutton, R.: The potential to narrow uncertainty in regional climate predictions, B. Am. Meteorol. Soc., 90, 10951107, https://doi.org/10.1175/2009BAMS2607.1, 2009.

Hawkins, E. and Sutton, R.: The potential to narrow uncertainty in projections of regional precipitation change, Clim. Dynam., 37, 407-418, https://doi.org/10.1007/s00382-010-0810-6, 2010.

Hawkins, E., Anderson, B., Diffenbaugh, N., Mahlstein, I., Betts, R., Hegerl, G., Joshi, M., Knutti, R., McNeall, D., Solomon, S., Sutton, R., Syktus, J., and Vecchi, G.: Uncertainties in the timing of unprecedented climates, Nature, 511, E3-E5, https://doi.org/10.1038/nature13523, 2014.

Homma, T. and Saltelli, A.: Importance measures in global sensitivity analysis of nonlinear models, Reliab. Eng. Syst. Safe., 52, 1-17, https://doi.org/10.1016/0951-8320(96)00002-6, 1996.

Hwang, S. and Graham, W. D.: Development and comparative evaluation of a stochastic analog method to downscale daily GCM precipitation, Hydrol. Earth Syst. Sci., 17, 4481-4502, https://doi.org/10.5194/hess-17-4481-2013, 2013.

Hwang, S. and Graham, W. D.: Assessment of Alternative Methods for Statistically Downscaling Daily GCM Precipitation Outputs to Simulate Regional Streamflow, Journal of the American Water Resources Association (JAWRA) 50, 1010-1032, https://doi.org/10.1111/jawr.12154, 2014.
Hwang, S., Graham, W. D., Adams, A., and Geurink, J.: Assessment of the utility of dynamically-downscaled regional reanalysis data to predict streamflow in west central Florida using an integrated hydrologic model, Reg. Environ. Change, 13, 69-80, https://doi.org/10.1007/s10113-013-0406-x, 2013.

Hwang, S., Graham, W. D., Geurink, J. S., and Adams, A.: Hydrologic implications of errors in bias-corrected regional reanalysis data for west central Florida, J. Hydrol., 510, 513-529, https://doi.org/10.1016/j.jhydrol.2013.11.042, 2014.

Ines, A. V. M. and Hansen, J. W.: Bias correction of daily GCM rainfall for crop simulation studies, Agr. Forest. Meteorol., 138 , 44-53, https://doi.org/10.1016/j.agrformet.2006.03.009, 2006.

Irmak, S., Odhiambo, L. O., Kranz, W. L., and Eisenhauer, D. E.: Irrigation Efficiency and Uniformity, and Crop Water Use Efficiency, Biological Systems Engineering: Papers and Publication, available at: https://digitalcommons.unl.edu/ biosysengfacpub/451 (last access: 10 September 2018), 2011.

Jackson, M. C. and Albritton, B.: 2011 Estimated Water Use Report, Brooksville, FL, 2013

Jacobs, J. and Dukes, M.: Revision of AFSIRS crop water simulation model, Summary, St. Johns River Water Management District, Palatka, FL, 2007.

Ji, D., Wang, L., Feng, J., Wu, Q., Cheng, H., Zhang, Q., Yang, J., Dong, W., Dai, Y., Gong, D., Zhang, R.-H., Wang, X., Liu, J., Moore, J. C., Chen, D., and Zhou, M.: Description and basic evaluation of Beijing Normal University Earth System Model (BNU-ESM) version 1, Geosci. Model Dev., 7, 2039-2064, https://doi.org/10.5194/gmd-7-2039-2014, 2014.

Kay, A. L. and Davies, H. N.: Calculating potential evaporation from climate model data: A source of uncertainty for hydrological climate change impacts, J. Hydrol., 358, 221-239, https://doi.org/10.1016/j.jhydrol.2008.06.005, 2008.

Kingston, D. G., Todd, M. C., Taylor, R. G., Thompson, J. R., and Arnell, N. W.: Uncertainty in the estimation of potential evapotranspiration under climate change, Geophys. Res. Lett., 36, L20403, https://doi.org/10.1029/2009GL040267, 2009.

Kløve, B., Ala-Aho, P., Bertrand, G., Gurdak, J. J., Kupfersberger, H., Kværner, J., Muotka, T., Mykrä, H., Preda, E., Rossi, P., Uvo, C. B., Velasco, E., and Pulido-Velazquez, M.: Climate change impacts on groundwater and dependent ecosystems, J. Hydrol., 518, 250-266, https://doi.org/10.1016/j.jhydrol.2013.06.037, 2014.

Koedyk, L. P. and Kingston, D. G.: Potential evapotranspiration method influence on climate change impacts on river flow: a mid-latitude case study, Hydrol. Res., 47, 951-963, https://doi.org/10.2166/nh.2016.152, 2016.

Kundzewicz, Z. W., Mata, L. J., Arnell, N. W., Döll, P., Jimenez, B., Miller, K., Oki, T., Şen, Z., and Shiklomanov, I.: The implications of projected climate change for freshwater resources and their management, Hydrolog. Sci. J., 53, 3-10, https://doi.org/10.1623/hysj.53.1.3, 2008.

Kundzewicz, Z. W., Mata, L. J., Arnell, N. W., Döll, P., Jimenez, B., Miller, K., Oki, T., and Şen, Z.: Water and climate projections, Hydrolog. Sci. J., 54, 406-415, https://doi.org/10.1623/hysj.54.2.406, 2009.

Langousis, A., Mamalakis, A., Deidda, R., and Marrocu, M.: Assessing the relative effectiveness of statistical downscaling and distribution mapping in reproducing rainfall statistics based 
on climate model results, Water Resour. Res., 52, 471-494, https://doi.org/10.1002/2015WR017556, 2016.

Lin, B., Chen, X., Yao, H., Chen, Y., Liu, M., Gao, L., and James, A.: Analyses of landuse change impacts on catchment runoff using different time indicators based on SWAT model, Ecol. Indic., 58, 55-63, https://doi.org/10.1016/j.ecolind.2015.05.031, 2015.

Liu, M., Adam, J. C., and Hamlet, A. F.: Spatial-temporal variations of evapotranspiration and runoff/precipitation ratios responding to the changing climate in the pacific northwest during 1921-2006, J. Geophys. Res.-Atmos., 118, 380-394, https://doi.org/10.1029/2012JD018400, 2013.

Ma, Z. M., Kang, S. Z., Zhang, L., Tong, L., and Su, X. L.: Analysis of impacts of climate variability and human activity on streamflow for a river basin in arid region of northwest China, J. Hydrol., 352, 239-249, https://doi.org/10.1016/j.jhydrol.2007.12.022, 2008.

Matheussen, B., Kirschbaum, R. L., Goodman, I. A., O'Donnell, G. M., and Lettenmaier, D. P.: Effects of land cover change on streamflow in the interior Columbia River Basin (USA and Canada), Hydrol. Process., 14, 867-885, https://doi.org/10.1002/(SICI)10991085(20000415)14:5<867::AID-HYP975>3.0.CO;2-5, 2000.

Maurer, E. P. and Hidalgo, H. G.: Utility of daily vs. monthly large-scale climate data: an intercomparison of two statistical downscaling methods, Hydrol. Earth Syst. Sci., 12, 551-563, https://doi.org/10.5194/hess-12-551-2008, 2008.

Maurer, E. P., Hidalgo, H. G., Das, T., Dettinger, M. D., and Cayan, D. R.: The utility of daily large-scale climate data in the assessment of climate change impacts on daily streamflow in California, Hydrol. Earth Syst. Sci., 14, 1125-1138, https://doi.org/10.5194/hess-14-1125-2010, 2010.

McAfee, S. A.: Methodological differences in projected potential evapotranspiration, Climatic Change, 120, 915-930, https://doi.org/10.1007/s10584-013-0864-7, 2013.

Milliman, J. D., Farnsworth, K. L., Jones, P. D., Xu, K. H., and Smith, L. C.: Climatic and anthropogenic factors affecting river discharge to the global ocean, 1951-2000, Global Planet. Change, 62, 187-194, https://doi.org/10.1016/j.gloplacha.2008.03.001, 2008.

Mood, A. M., Graybill, F. A., and Boes, D. C.: Introduction to theory of statistics, McGraw-Hill, Inc., New York City, NY, USA, 1974.

Muerth, M. J., Gauvin St-Denis, B., Ricard, S., Velázquez, J. A., Schmid, J., Minville, M., Caya, D., Chaumont, D., Ludwig, R., and Turcotte, R.: On the need for bias correction in regional climate scenarios to assess climate change impacts on river runoff, Hydrol. Earth Syst. Sci., 17, 1189-1204, https://doi.org/10.5194/hess-17-1189-2013, 2013.

Murray, S. J., Foster, P. N., and Prentice, I. C.: Future global water resources with respect to climate change and water withdrawals as estimated by a dynamic global vegetation model, J. Hydrol., 448-449, 14-29, https://doi.org/10.1016/j.jhydrol.2012.02.044, 2012.

Patterson, L. A., Lutz, B., and Doyle, M. W.: Climate and direct human contributions to changes in mean annual streamflow in the South Atlantic , USA, Water Resour. Res., 49, 7278-7291, https://doi.org/10.1002/2013WR014618, 2013.

Quintana Seguí, P., Ribes, A., Martin, E., Habets, F., and Boé, J.: Comparison of three downscaling methods in simulating the impact of climate change on the hydrology of Mediterranean basins, J. Hydrol., 383, 111-124, https://doi.org/10.1016/j.jhydrol.2009.09.050, 2010.

Regional Water Supply Planning, Florida Department of Environmental Protection, Tallahassee, Florida, 2016.

Rupp, D. E.: An evaluation of 20th century climate for the Southeastern United States as simulated by Coupled Model Intercomparison Project Phase 5 (CMIP5) global climate models, U.S. Geological Survey, Open-File Report 2016-1047, 32 pp., https://doi.org/10.3133/ofr20161047, 2016.

Saltelli, A.: Sensitivity analysis: Could better methods be used?, J. Geophys. Res., 104, 3789-3793, https://doi.org/10.1029/1998JD100042, 1999.

Saltelli, A., Ratto, M., Andres, T., Campolongo, F., Cariboni, J., Gatelli, D., Saisana, M., and Tarantola, S.: Global sensitivity analysis: the primer, John Wiley \& Sons, Inc., Hoboken, NJ, USA, 2008.

Saltelli, A., Annoni, P., Azzini, I., Campolongo, F., Ratto, M., and Tarantola, S.: Variance based sensitivity analysis of model output. Design and estimator for the total sensitivity index, Comput. Phys. Commun., 181, 259-270, https://doi.org/10.1016/j.cpc.2009.09.018, 2010.

Siriwardena, L., Finlayson, B. L., and McMahon, T. A.: The impact of land use change on catchment hydrology in large catchments: The Comet River, Central Queensland, Australia, J. Hydrol., 326 , 199-214, https://doi.org/10.1016/j.jhydrol.2005.10.030, 2006.

Smajstrla, A. G.: Technical Manual: Agricultural field scale irrigation requirements simulation (AFSIRS) model, Version 5.5, Gainesville, FL, 1990.

Solomon, S., Qin, D., Manning, M., Alley, R. B., Berntsen, T., Bindoff, N. L., Chen, Z., Chidthaisong, A., Gregory, J. M., Hegerl, G. C., Heimann, M., Hewitson, B., Hoskins, B. J., Joos, F., Jouzel, J., Kattsov, V., Lohmann, U., Matsuno, T., Molina, M., Nicholls, N., Overpeck, J., Raga, G., Ramaswamy, V., Ren, J., Rusticucci, M., Somerville, R., Stocker, T. F., Whetton, P., Wood, D., and Wratt, R. A.: Climate Change 2007: The Physical Science Basis, Contribution of Working Group I to the Fourth Assessment Report of the Intergovernmental Panel on Climate Change, edited by: Solomon, S., Qin, D., Manning, M., Chen, Z., Marquis, M., Averyt, K. B., Tignor, M., and Miller, H. L., Cambridge University Press, Cambridge, United Kingdom and New York, NY, USA, 2007.

Stoll, S., Hendricks Franssen, H. J., Butts, M., and Kinzelbach, W.: Analysis of the impact of climate change on groundwater related hydrological fluxes: a multi-model approach including different downscaling methods, Hydrol. Earth Syst. Sci., 15, 21-38, https://doi.org/10.5194/hess-15-21-2011, 2011.

Tampa Bay Water: Water Demand Management Plan, Final Report, Hazen and Sawyer, 274 pp., 2013.

Tan, X. and Gan, T. Y.: Contribution of human and climate change impacts to changes in streamflow of Canada, Sci. Rep., 5, 17767, https://doi.org/10.1038/srep17767, 2015.

Tariq, A., Lempert, R. J., Riverson, J., Schwartz, M., and Berg, N.: A climate stress test of Los Angeles' water quality plans, Climatic Change, 144, 625-639, https://doi.org/10.1007/s10584017-2062-5, 2017.

Taylor, K. E., Stouffer, R. J., and Meehl, G. A.: An Overview of CMIP5 and the Experiment Design, B. Am. Meteorol. Soc., 93, 485-498, https://doi.org/10.1175/BAMS-D-11-00094.1, 2012. 
Teutschbein, C. and Seibert, J.: Bias correction of regional climate model simulations for hydrological climate-change impact studies: Review and evaluation of different methods, J. Hydrol., 456457, 12-29, https://doi.org/10.1016/j.jhydrol.2012.05.052, 2012.

Thompson, J. R., Green, A. J., and Kingston, D. G.: Potential evapotranspiration-related uncertainty in climate change impacts on river flow: An assessment for the Mekong River basin, J. Hydrol., 510, 259-279, https://doi.org/10.1016/j.jhydrol.2013.12.010, 2014.

Tihansky, A. B.: Sinkholes, west-central Florida, U.S. Geological Survey, Tampa, FL, 1999.

Tihansky, A. B. and Knochenmus, L. A.: Karst features and hydrogeology in west-central Florida - A field perspective, in: U.S. Geological Survey Karst Interest Group Proceedings, edited by: Kuniansky, E. L., U.S. Geological Survey, Water-Resources Investigations Report 01-4011, 198-211, avalable at: http://water.usgs.gov/ogw/karst/kigconference/abt_ karstfeatures.htm (last access: 1 September 2018), 2001.

Vano, J. A. and Lettenmaier, D. P.: A sensitivity-based approach to evaluating future changes in Colorado River discharge, Clim. Change, 122, 621-634, https://doi.org/10.1007/s10584013-1023-x, 2013.

Vorosmarty, C. J., Green, P., Salisbury, J., and Lammers, R. B.: Global Water Resources: Vulnerability from Climate Change and Population Growth, Science, 289, 284-288, https://doi.org/10.1126/science.289.5477.284, 2000.

Walsh, J., Wuebbles, D., Hayhoe, K., Kossin, J., Stephens, G., Thorne, P., Vose, R., Wehner, M., Willis, J., Anderson, D., Doney, S., Feely, R., Hennon, P., Kharin, V., Knutson, T., Landerer, F., Lenton, T., Kennedy, J., and Somerville, R.: Ch. 2: Our Changing Climate, in: Climate Change Impacts in the United States: The Third National Climate Assessment, edited by: Melillo, J. M., Richmond, T. (T.C.), and Yohe, G. W., U.S. Global Change Research Program, 19-67, https://doi.org/10.7930/J0KW5CXT, 2014.

Wang, D. and Hejazi, M.: Quantifying the relative contribution of the climate and direct human impacts on mean annual streamflow in the contiguous United States, Water Resour. Res., 47, W00J12, https://doi.org/10.1029/2010WR010283, 2011.

Wang, W., Xing, W., and Shao, Q.: How large are uncertainties in future projection of reference evapotranspiration through different approaches?, J. Hydrol., 524, 696-700, https://doi.org/10.1016/j.jhydrol.2015.03.033, 2015.
Watanabe, S., Hajima, T., Sudo, K., Nagashima, T., Takemura, T., Okajima, H., Nozawa, T., Kawase, H., Abe, M., Yokohata, T., Ise, T., Sato, H., Kato, E., Takata, K., Emori, S., and Kawamiya, M.: MIROC-ESM 2010: model description and basic results of CMIP5-20c3m experiments, Geosci. Model Dev., 4, 845-872, https://doi.org/10.5194/gmd-4-845-2011, 2011.

Wood, A. W., Maurer, E. P., Kumar, A., and Lettenmaier, D. P.: Long-range experimental hydrologic forecasting for the eastern United States, J. Geophys. Res., 107, 4429, https://doi.org/10.1029/2001JD000659, 2002.

Xiao-Ge, X., Tong-Wen, W., Jiang-Long, L., Zai-Zhi, W., WeiPing, L., and Fang-Hua, W.: How well does BCC_CSM1. 1 reproduce the 20th century climate change over China?, Atmospheric and Oceanic Science Letters, 6, 21-26, available at: http://159.226.119.58/aos1/CN/article/downloadArticleFile. do?attachType=PDF\&id=332 (last access: 12 January 2015), 2013.

Yan, B., Fang, N. F., Zhang, P. C., and Shi, Z. H.: Impacts of land use change on watershed streamflow and sediment yield: An assessment using hydrologic modelling and partial least squares regression, J. Hydrol., 484, 26-37, https://doi.org/10.1016/j.jhydrol.2013.01.008, 2013.

Ye, X., Zhang, Q., Liu, J., Li, X., and Xu, C.: Distinguishing the relative impacts of climate change and human activities on variation of streamflow in the Poyang Lake catchment, China, J. Hydrol., 494, 83-95, https://doi.org/10.1016/j.jhydrol.2013.04.036, 2013.

Yukimoto, S., Adachi, Y., Hosaka, M., Sakami, T., Yoshimura, H., Hirabara, M., Tanaka, T. Y., Shindo, E., Tsujino, H., Deushi, M., Mizuta, R., Yabu, S., Obata, A., Nakano, H., Koshiro, T., Ose, T., and Kitoh, A.: A New Global Climate Model of the Meteorological Research Institute: MRI-CGCM3 - Model Description and Basic Performance, Journal of the Meteorological Society of Japan, Ser. II, 90A, 23-64, https://doi.org/10.2151/jmsj.2012A02, 2012.

Zhang, F. and Georgakakos, A. P.: Joint variable spatial downscaling, Climatic Change, 111, 945-972, https://doi.org/10.1007/s10584-011-0167-9, 2012.

Zheng, H., Zhang, L., Zhu, R., Liu, C., Sato, Y., and Fukushima, Y.: Responses of streamflow to climate and land surface change in the headwaters of the Yellow River Basin, Water Resour. Res. 45, https://doi.org/10.1029/2007WR006665, 2009.

Zieyel, E. R.: The Collected Works of John W. Tukey, Technometrics, 30, 363-363, https://doi.org/10.1080/00401706.1988.10488428, 1988. 